\title{
برنامج تربية متحفية لتنمية بعض المفاهيم الحضارية لدى طفل الحضانة من (r)
}

إعداد

الباحثة/ رنا علاء الدين عبد المنعم'

\section{| - الإشراف}

أ.م.د جيهان عبد الفتاح عزام

أستاذ مناهج الطقل المساعد ورئيس قسم الطلوم

الأساسية- كلية التربية للطفولة المبكرة

جامعة القاهرة
أ.م.د سعاد السيد إبراهيم

أستاذ التربية الرياضية المساعد

كلية التربية للطفولة المبكرة

جامعة القاهرة

\section{داطمة حسن على مانى}

مدرس بقسم العلوم الأساسية - كلية التربية للطقولة المبكرة- جامعة القاهرة

مقدمة البحث:

تعتبر مرحلة دور الحضانة من أهم المراحل التى تتشكل فيها شخصية الطفل، وهى أساس للتربية السليمة، فالأربع سنوات الأولى من حياة الطفل تمنك الركيزة الأساسية لنمو جميع جوانبه الجسمية والعقلية والنفسية والإجتماعية ، فطفل هذه المرحلة سهل التأثر شديد المرونة لكل ما يتعلمه، كما يتميز بالنشاط والحيوية واللعب ولديه رغبة فى المعرفة والاكتشاف، مما يساهم ذلك فى اكسابه العديد من العادات والمفاهيم والقيم والاتجاهات الإيجابية حتى ينشأ فرد صالح لنفسه ولمجتمعه. فطفل اليوم هو رجل الغد وصانعه وانه الثروة الكبرى للوطن والأمة، فإن أُحسن تربيته وتوجيهه بشكل إيجابى يتحقق التقدم والرقى للوطن، فيجب أن تتكاتف جميع المؤسسات الاجتماعية والتقافية لإعداده وتربيته تربية صالحة، فضلاً عن أهمية تعاون الأسرة مع دور الحضانة فى غرس القيم والمثل العليا فى ولى نفوس الأطفال.

وتعد المتاحف من أهم المؤسسات التى تحافظ على الموروث الحضارى، بما تحتوى عليه من محفوظات عديدة ذات قيمة نراثية عاليه يُعكس من خلالها عظمة الحضارة المصرية عبر السنين، فضلاً عن دورها فى حفظ التراث الإنسانى لكى تتوارثه الأجيال القادمة، فهى تعتبر بمثابة أداء لربط ماضى الإنسان

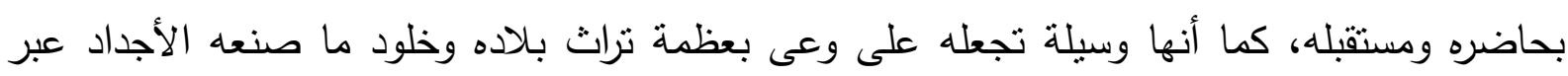
العصور ، وذللك لتقوية الروح الوطنية والانتماء لايه.

'مدرس مساعد ـ قسم العلوم الأساسية ـ كلية التربية للطقلولة المبكرة ـ جامعة القاهرة. (باحثة دكتوراه) 
ونجد أن التربية المتحفية أصبحت ضرورة ملحة فى تربية الأطفال منذ الصغر وتتمية انتمائهم، فمن

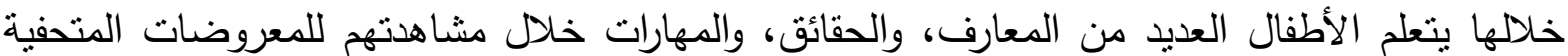
واستكثاف النماذج والأدوات باستخدام حواسهم فى فهم الأفكار التى تعبر عنها، وممارستهم للأنشطة ونطات المتحفية التى تساعدهم على إثراء وتدعيم معلوماتهم ومعارفهم وخبراتهم .

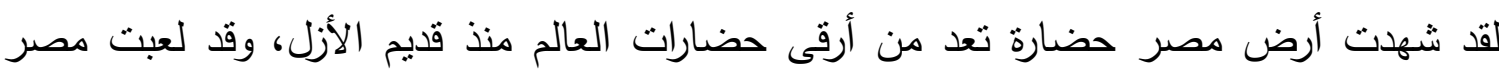
الفرعونية دوراً هاماً فى الرقى الحضارى الإنسانى، والأطفال منذ نعومة أظافرهم، بحاجة ضرورية لمعرفة تاريج وحضارة بلادهم؛ حتى يمكن لهم من ممارسة أدوراهم بشكل جيد فى الحاضر والمستقبل، للاعتزاز والانتماء بما صنعه لنا الأجداد من ميراث حضارى عريق. وقد أوضحت العديد من الدراسات دور المتاحف والتربية المتحفية فى نشر التقافة والمعرفة للنشء بإعتبار المتحف مؤسسة تربوية وتعليمية، كما أثنار العديد منها على على أهمية معرفة النشء بحضارة وتاريخ بلادهم ومن هذه الدراسات: دراسة شانج فانج Lee Ching -Fang (2002) إلى ضرورة الاهتمام بالمتحف ككيان تعليمى وليس فقط اعتباره مكان للإطلاع على المعروضات والأعمال الفنية به، وانما لابد من ادخاله كعنصر هام للتعليم فى الددراس للأطفال والطلاب وتوصليه لهم لنشر العلم والثقافة،

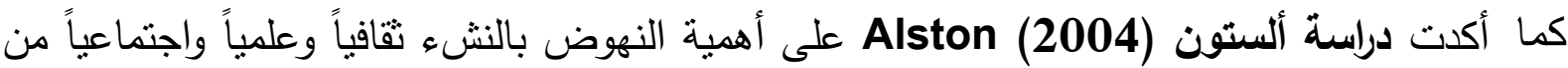
خلال برامج تراثية وتاريخية تربوية تهدف إلى التعرف على النتاج التاريخى الذى انتجه الإنسان خلال الحقب التاريخية المختلفة، وذلك بهذف بناء إيجابى لنخصية النشء، وتوصلت دراسة رويرت برائ وراندى Robert Shumer, Randy Bechtl (2006)

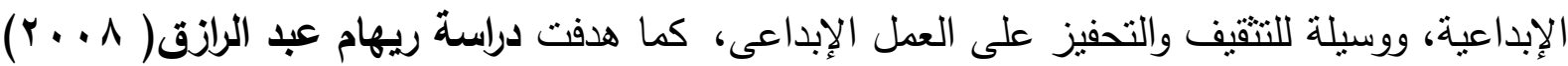
إلى إكساب الثقافة المتحفية لأطفال ما قبل الدرسة لما لها من تأثير على شخصية الطفل فتكسبه ثروات ثقافية ومهارات ذاتية تساعده على رسم مستقلبه فى ظل حبه لوطنه وانتمائه له، كما توصلت دراسة آمال

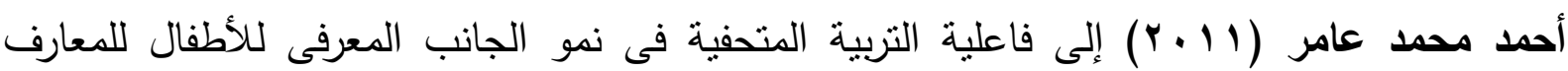

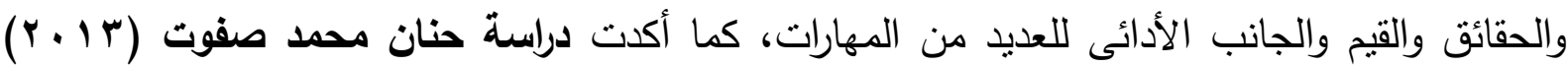

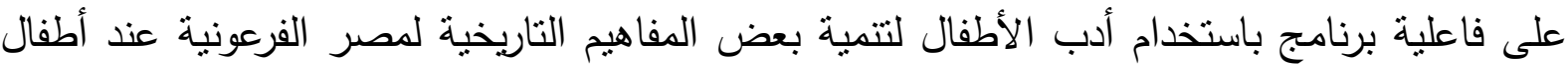
الروضة.

وفى ضوء ما سبق وجدت الباحثة أن المتحف مؤسسة تربوية تعليمية تتقيفية لا تقل أهميته عن باقى المؤسسات التربوية وأن برامج التربية المتحفية لها أهميتها فى تربية وتعليم النشء تاريخ وحضارة بلادهم وأكساب الطفل العديد من المعارف والمهارات والقيم والاتجاهات، وبالنظر للعديد من الدراسات العربية والاجنبية وجدت الباحثة أنها اهتمت بمرحلة الروضة ولم تجد دراسات فى حدود علمها أهتمت ببرامج التربية المتحفية لمرحلة دور الحضانة ومن هنا ظهرت مشكلة البحث. 
مشكلة البحث:

لقد بدأ إحساس الباحثة بمشكلة البحث بحكم عملها بكلية التربية للطفولة المبكرة مما بتسنى لها الإثراف على طالبات التربية العملى الفرقة الثالثة والرابعة فى العديد من دور الحضانة، حيث لاحظت عدم الاهنمام بالزيارات الميدانية وخاصة المتحفية، بالإضافة إلى قصور فى تقديم الأنشطة المتحفية التى

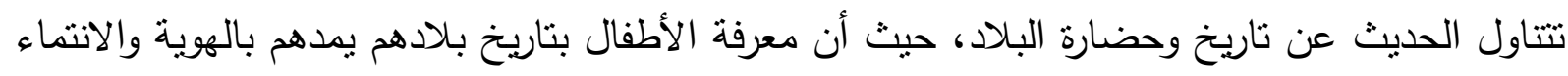
وبخاصة تاريخ مصر الفرعونية لما له من دور فى ترسيخ مراحل التاريخ الأخرى لكى يتعلم الأطفال أصل التاريخ الذى يأتى إليه السائحين من جميع إنحاء العالم، كما لاحظت الباحثة ان مرحلة دور

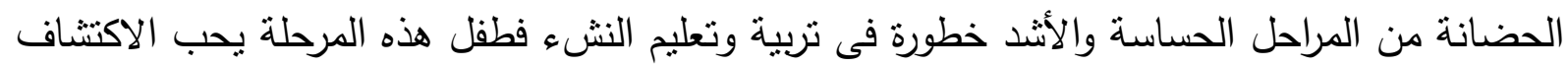
والإطلاع واستخدام كافة حواسه للبحث والمعرفة لذا اختارت الباحثة المتحف كسبيل لذلك، واقتصرت الباحثة المفاهيم الحضارية على حضارة مصر الفرعونية فقط لتكون سهلة الفهم والاستيعاب لمرحلة دور الحضانة من (ب-乏) سنوات، كل هذا دفع الباحثة إلى تبنى مشكلة البحث، ولذا يسعى البحث الحالى إلى وضع برنامج تربية متحفية لتتمية بعض المفاهيم الحضارية لمصر الفرعونية وذلك لمرحلة طفل الحضانة من (r-

\section{ويمكن صياغة مشكلة البحث فى السؤال التالى:}

ما دور برنامج التربية المتحفية فى تتمية بعض المفاهيم الحضارية لمصر الفرعونية لدى طفل الحضانة (ب-乏) سنوات؟ ويتفرع منه عدة أسئلة: ا- ما أبعاد المفاهيم الحضارية لمصر الفرعونية الواجب تتميتها لدى طفل الحضانة من (r-ع) سنوات؟ r- ما دور التربية المتحفية فى تتمية بعض المفاهيم الحضارية لمصر الفرعونية لدى طفل الحضانة

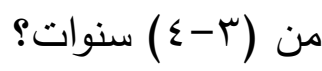
r- ما فاعلية برنامج التربية المتحفية فى تتمية بعض المفاهيم الحضارية لمصر الفرعونية لدى طفل الحضانة من (r-ع) سنوات ؟ أهداف البحث : n 1- تحديد أبعاد المفاهيم الحضارية لمصر الفرعونية المناسبة لطفل الحضانة من (r-ع) سنوات. r- تحديد برنامج التربية المتحفية الخاص بتتمية بعض المفاهيم الحضارية لمصر الفرعونية لطفل الحضانة من (r- ( ) سنوات. r- - قياس فاعلية برنامج التربية المتحفية فى تتمية بعض المفاهيم الحضارية لمصر الفرعونية لطفل الحضانة من (r-乏) سنوات. 
ا - تبصير القائمين على التعليم ، والعاملين بالمتاحف ، والمهتمين بالطفولة الى اهمية الأنشطة

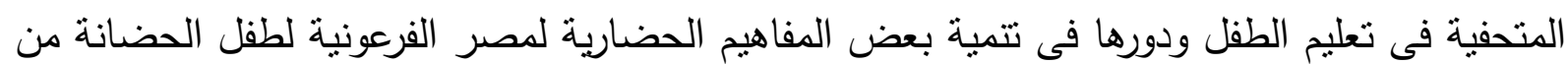
. r - إمكانية تعميم البرنامج وتصميم برامج مماتلة لتتمية بعض المفاهيم الحضارية لمصر الفرعونية لطفل الحضانة من (r-§) سنوات.. ץ- تزويد معلمات أو مشرفات الحضانة وأولياء الأمور ببرنامج فى التربية المتحفية لأطفال الحضانة من ( ) ( ) سنوات يساعدهم فى حالة ترددهم وزياراتهم للمتاحف المختلفة. ع - يمكن الإفادة من البرنامج فى عمليات تقويم وتطوير مجال دور الحضانة، كما قد يفيد هذا البحث فى خلق جيل جديد يعرف معنى الانتماء لمجتمعه ووطنه ولايه وعى حضارى بحضارة بلده العريقة، لكى يعرف اهميتها وكيفية تحقيق التقدم والرقى الدائم لها.

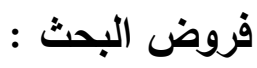
() توجد فروق ذات دلالة إحصائية بين منوسطات درجات أطفال المجموعة التجريبية وأطفال المجموعة الضابطة فى القياس البعدى على مقياس بعض المفاهيم الحضارية لمصر الفرعونية المصور لطفل الحضانة دن (r-ع) سنوات بعد تطبيق برنامج التربية المتحفية لصالح المجموعة التجريبية. Y) لا توجد فروق ذات دلالة إحصائية بين متوسطات درجات أطفال المجموعة الضابطة فى القياسين القبلى والبعدى على مقياس بعض المفاهيم الحضارية لمصر الفرعونية لطفل الحضانة من (س-ء) سنوات. r)توجد فروق ذات دلالة إحصائية بين منوسطات درجات أطفال المجموعة التجربيية فى القياسين القبلى والبعدى على مقياس بعض المفاهيم الحضارية لمصر الفرعونية المصور لطفل الحضانة من (r-ع) سنوات بعد تطبيق برنامج التربية المتحفية لصالح القياس البعدى . ع) نسبة التحسن لاى أطفال المجموعة التجريبية أعلى من أطفال المجموعة الضابطة مقياس بعض بل المفاهيم الحضارية لمصر الفرعونية المصور لطفل الحضانة دن (س-ع) سنوات 0) لا توجد فروق ذات دلالة إحصائية بين متوسطات درجات أطفال المجموعة التجربيية فى القياسين البعدى و التتبعى على مقياس بعض المفاهيم الحضارية لمصر الفرعونية المصور لطفل الحضانة من . مصطات البحث: () البرنامج: تعرفه الباحثة إجرائياً" بانه محتوى منظم يقوم على التربية المتحفية ويراعى متطلبات نمو طفل الحضانة من (r-乏) سنوات وذللك بتحقيق مجموعة من الأهداف التعليمية من خلال الممارسة 
العملية لمجموعة من الأنشطة المتحفية داخل قاعة النشاط بدور الحضانة والتى تهدف إلى تتمية بعض المفاهيم الحضارية لمصر الفرعونية بأستخدام بيئة تعليمية مناسبة وتفنيات ووسائل مساعدة على ذلك.

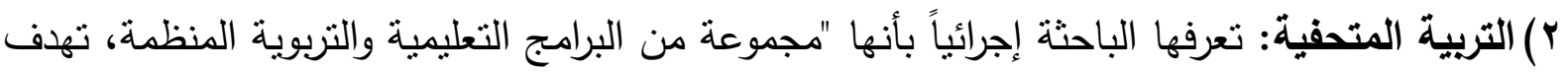

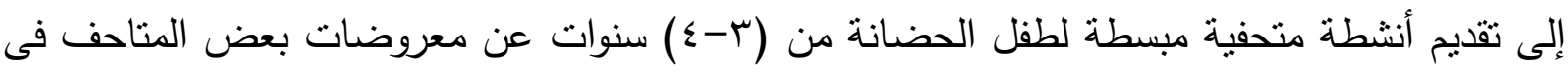
إطار من المتعة والتشلية التعليمية، لإثباع حاجاتهم للمعرفة وإكسابهم العديد من المعارف والمعلومات والمهارات المختلفة الناتجة عن قيامهم بممارسة العديد من الأنشطة المتحفية بإستخدام حواسهم المختلفة

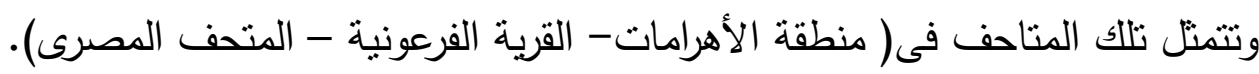

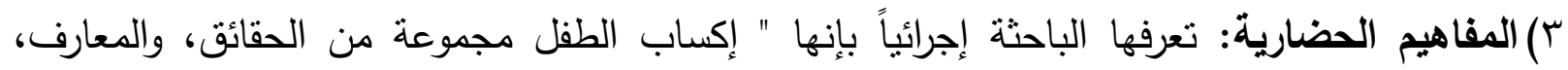

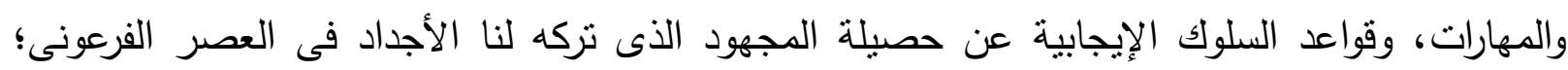
لإقامة حضارة مصرية عريقة، وتبسيط أبرز ما يميز الحضارة الفرعونية من نظم سياسية، وموارد اقتصادية، وتقاليد خلقية وعبادات دينية، وعلوم وفنون حضارية". ؛)طقل الحضانة: "هو نلك الطفل الذي لم يلتحق بعد بالروضة، ويكون ملتحقاً بدار الحضانة تحت رعاية

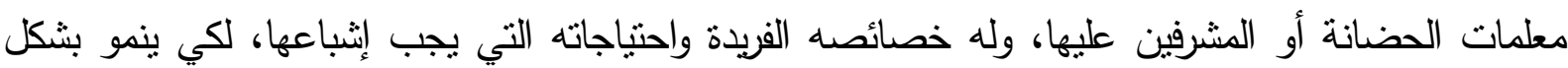
سوي، ويتزاوح عمره ما بين (r-§) سنوات". إطار نظرى ودراسات سابقة :

ويتناول الأطار النظرى محورين رئيسين التربية المتحفية- المفاهيم الحضارية. المحور الأول - التربية المتحفية: إزاد الاهتمام العالمى والمحلى بالمتاحف فى الآونة الأخيرة، حيث عقدت العديد من المؤتمرات

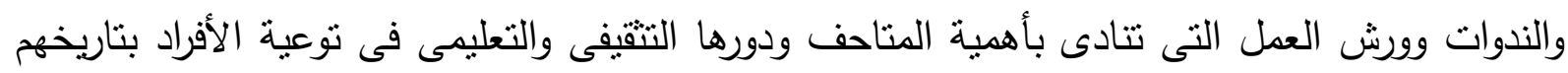

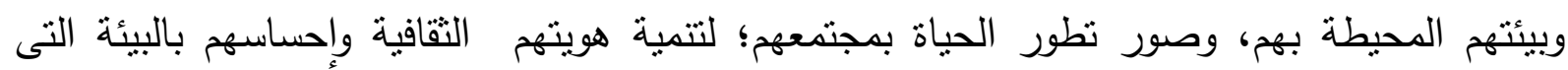
يعيشون فيها، فتقدم لنا على إختلاف أنواعها الموضوعات العلمية والفنية والتاريخية والحقب التاريخية للإنسان التى تؤثر على تربية الطفل وتعلمه القيم والعادات وتتكل إتجاهاته نحو مجتمعه.

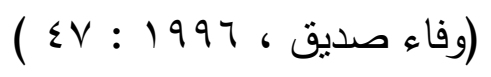

أولاًا - المتحف ودوره فى العملية التعليمية: تعمل المتاحف على إثباع احتياجات الأطفال واهتماماتهم ، وذللك بتوفير معارض وبرامج تستثير

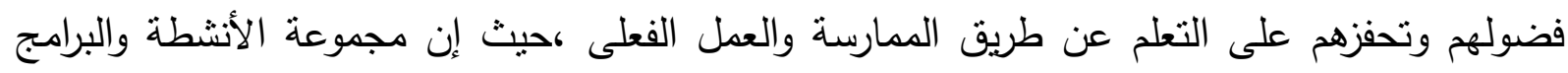

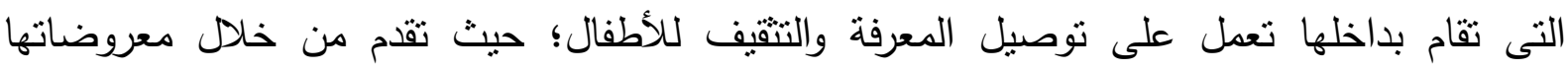
ومقتتياتها معلومات وحقائق متتوعة تتعلق بالإنسان والتطورات الحضارية التى مر بها عبر العصور

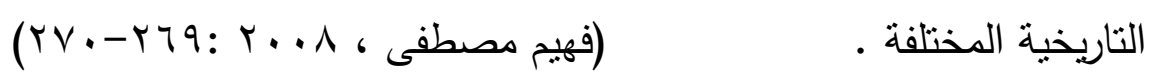




\section{تعريف المتحف:}

عرفه كل من سليفرمان وأونيل (40 : SilvermanL.H.\& M. O'Neill, 2004 المتحف بأنه

"سجلات موضوعية تجمع معلومات دقيقة وتتيحها ، فالمتحف هو مكان لحفظ الثقافة وصناعتها".

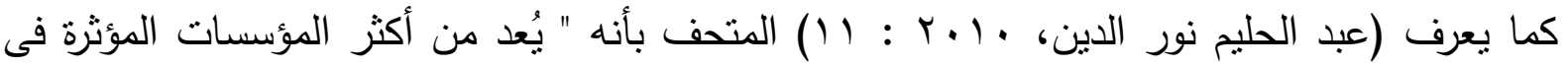

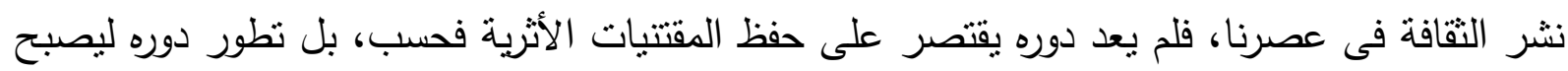

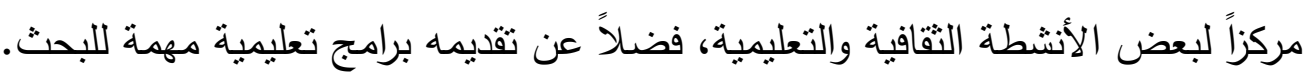

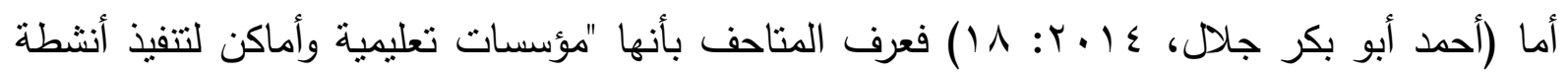
ثقافية منظمة من خلال برامج تربوية مدروسة ذات اغراض إيجابية تتماثىى مع جميع الأعمار . وتستخلص الباحثة مما سبق تعريف إجرائى للمتحف بأنه " مؤسسة تربوية تعليمية ثقافية ترفيهية تهدف الى حفظ وجمع التزاث الإنسانى ذى القيمة النقافية والحضارية الثينة، والذى يرجع إلى عصور

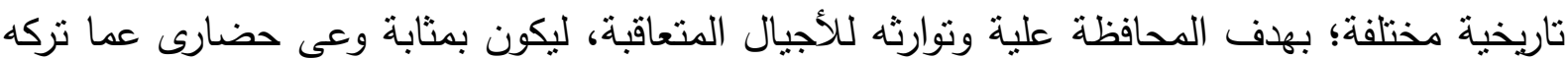
لنا الأسلاف من ميراث إنسانى وطبيعى للبشرية. دور المتحف كمؤسسة تريوية تعليمية:

ويمكن تحديد الدور الذى تسهم به المتاحف كمؤسسة تريوية تعليمية على النحو التالى:

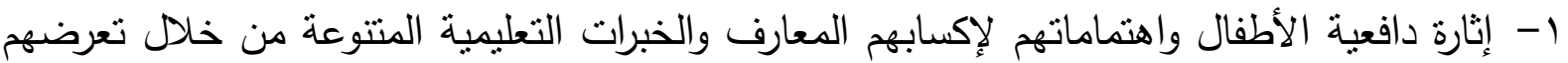
لمقتتبات المتحف ومعايشة ما برونه بطريقة علمية. r- إكساب الأطفال حقائق وخبرات ومهارات لا يستطيعون الحصول عليها من مكان آخر . r- مساعدة الأطفال على قضاء أوقات فراغهم بطريقة مسلية وشيقة بتقديم خبرات سارة ممتعة. ع -إثارة اهتمام الطفل بالبيئة الطبيعية المحيطة به، وتتجيعه على المحافظة عليها. 0-مساعدة الأطفال على إثباع رغباتهم وميولهم وتتمية قدراتهم وإكاناتهم . 7- إعطاء الطفل فرص الاستكثاف والبحث والتجريب لمحتويات المتحف.

V - نتجيع الطفل على احترام ميراثه التاريخى وتقوية شعوره بالاتنماء والتعرف على حضارة بلاده. 1- مساعدة الأطفال على الربط بين الأثياء التى يشاهدونها وما يتعلمونه فى المدرسة والمنزل.

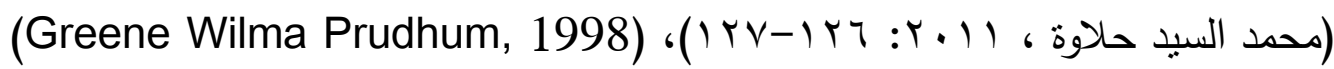
وقد أوضحت دراسة تورتلو Tortello , Rebecca (2002) أن للمتاحف دوراً فعالاً فى تطوير التعليم، وتحفيز التفكير النقدى والابتكارى، وتقدير الذات والآخرين لاى الأطفال ، كما أنها أماكن نابضة بالحياة يكتسب من خلالها الأطفال العديد من المعلومات . • أراء فلاسفة التربية وعلم النفس فى أهمية المتحف للطفل: يرى العديد من الفلاسفة الذين أسهموا بأفكارهم فى وضع الأساس النظرى لبرامج الطفل مثل

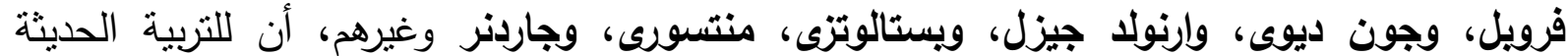


وظيفتين إحداهما فردية تعمل على تتمية الفرد كثخص قائم بذاته ويستمرفى تكوين عاداته وأفكاره حتى يصبح إلى فرد سوى مؤهل لنقل الحضارة، ووظيفة اجتماعية وهى تربيته بحيث يتكيف مع البيئة المحيطة

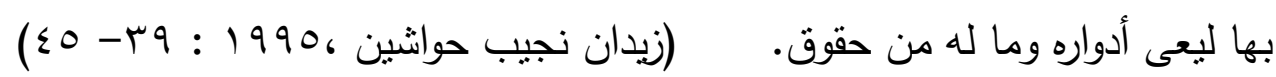

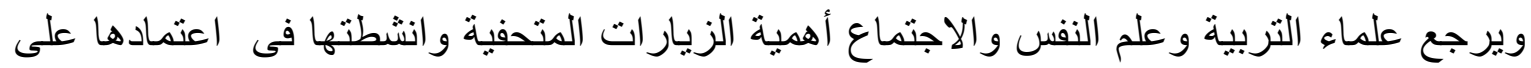

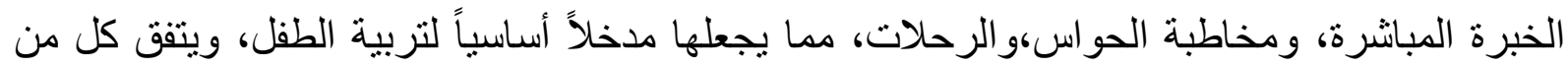

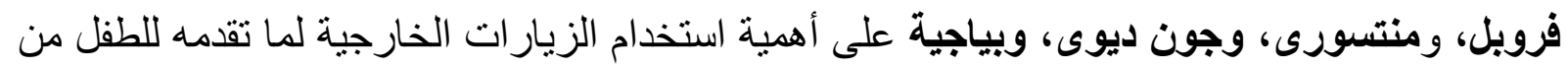
فرص الملاحظة والبحث والاستكثاف للييئة المحيطة بهم، مما بساعدعلى إنباع فضوله الهيه العلمى

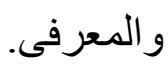

(Kinder, Anna M. , 2005 : 23-26), (Golobeck, Susan L,2002: 56-60)

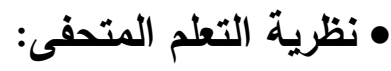
وجاءت نظرية "هين" لتعلم المتحفى نتيجة لتعدد أنماط الممارسات التعليمية بالمتاحف كان لابد

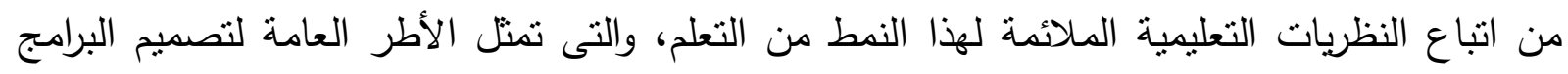

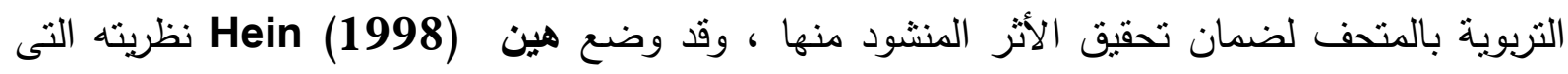

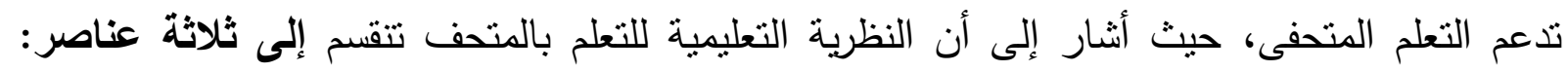

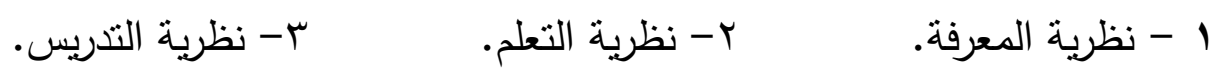

حيث يمثل العنصران الأول والثانى الأساس النظرى لما يقوم به المتحف كمؤسسة نعليمية، أما العنصر الثالث فيحدد كيفية وضع هذا الأساس النظرى فى سياق الممارسة والنطبيق. وفى ضوء اراء فلاسفة التربية وعلم النفس ونظريات التعلم المتحفى ظهر اتجاه حديث للاهتمام بدور

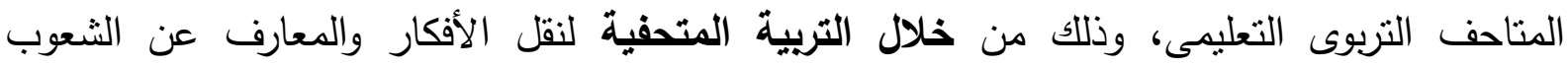
والجماعات والنظم الاجتماعية عن طريق إعداد المتاحف للخطط والبرامج والأنشطة العلمية والابتكارية.

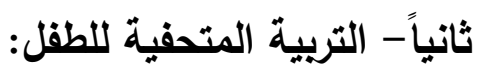

تعد التربية المتحفية من أهم النظم التعليمية المتعارف عليها عالمياً وبخاصة فى المجتمعات المنقدمة ، فقد نادت منظمة اليونسكو ومنظمة المتاحف العالمية (ICOM) بضرورة نوصيل المتاحف للمعرفة والثقافة عن طريق الحوار والمناقثة والملاحظة بشكل مباشر كأساس للتربية المتحفية التى تساعد فى التى

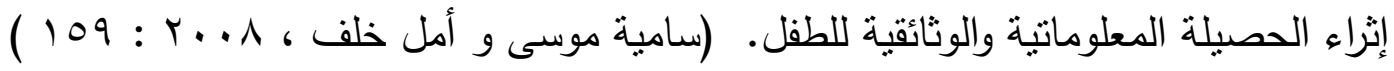
• تعريف التربية المتحفية:

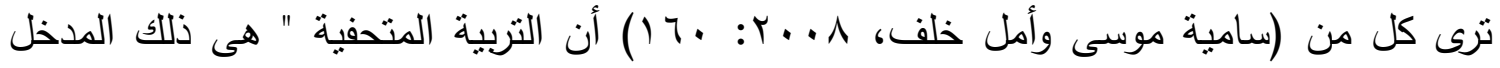
القائم على تقديم برامج تعليمية وورش عمل مبسطة ومنطورة تتماثى مع أعمار الأطفال ونقافاتهم 
وتفاعلهم مع المعروضات حيث يتعلم الأطفال عن طريق استخدام حواسهم وعن طريق العمل ويقومون

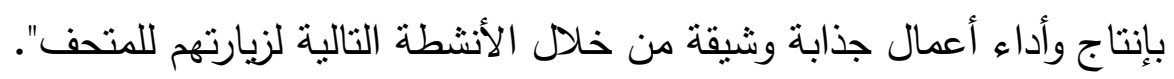

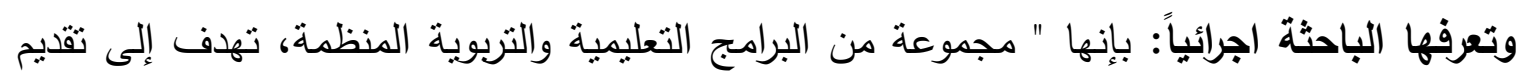

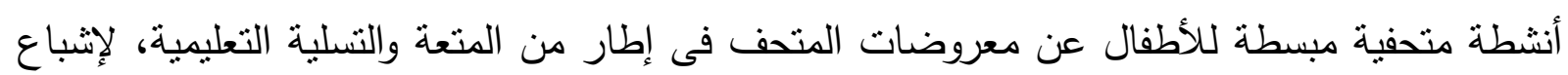

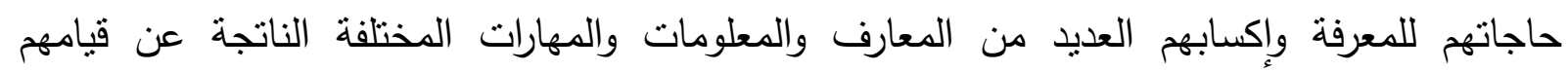

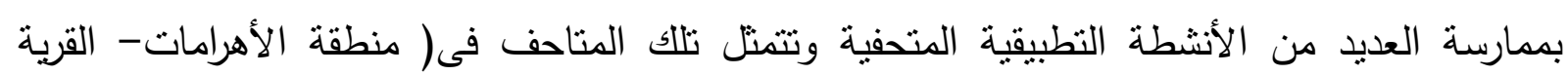
الفرعونية - المتحف المصرى)".

أهداف التربية المتحفية : وفيما يلى عرض لأهداف التربية المتحفية :

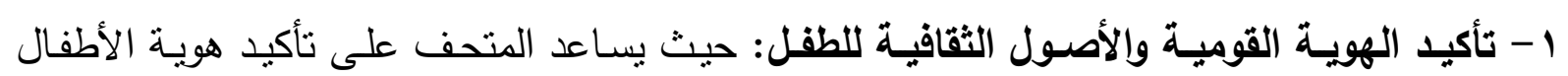
وتعرفهم على تاريخ حضارة وطنه وتمييز الاختلاف بين ثقافتهم والثقافات الأخرى.

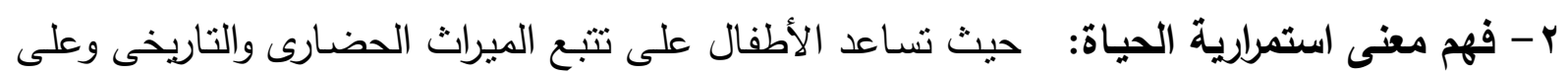

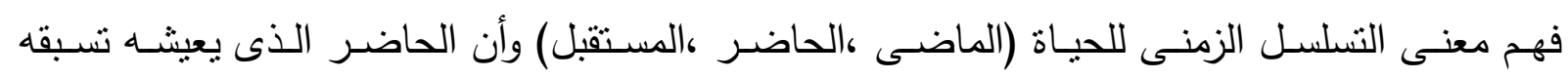
حضارات أخرى قديمة. ب- تنمية الفكر والمعرفة: حيث تستثير التربية المتحفية فكر الطفل وتجعله نشطاً وقادراً على استبعاب

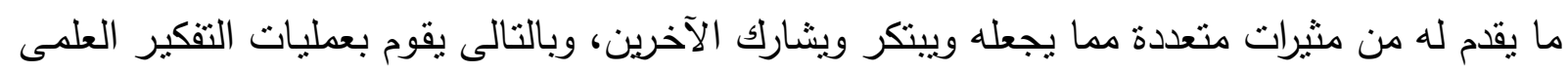
من فهم واستتناج والتنبؤ. ع - ممارسة الأنشطة التعبيرية والفنية: حيث يسمح للطفل بلمس المعروضات ورؤيتها ويمارس الأنشطة الفنية مثل الرسم أو التشكيل بالصلصال أو الورق المقوى للتوصل إلى حلول وأفيله وأفكار جديدة.

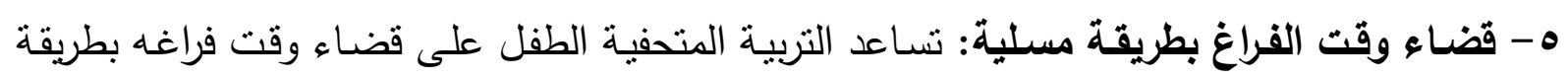
مسلية وممتعة بمعايشته لموضوعات من مواقف الحياة.

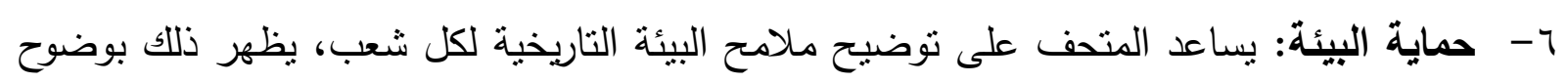

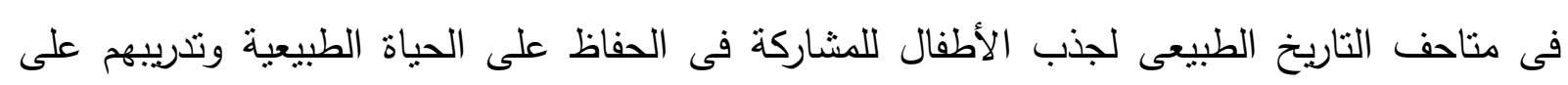

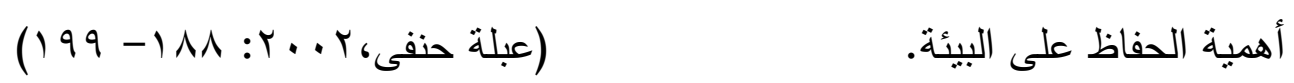

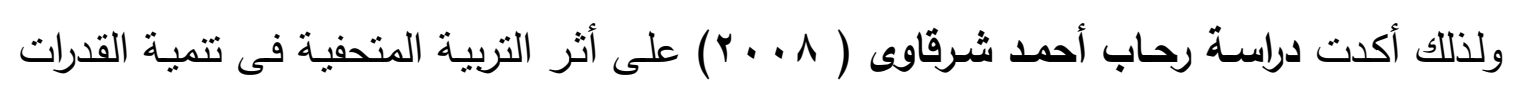

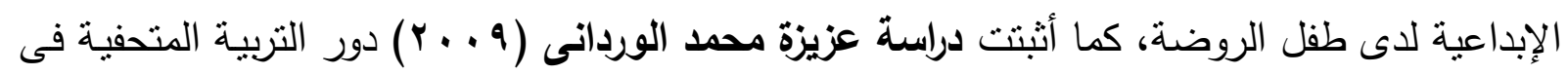
تبسيط بعض المفاهيم الجيولوجية لطفل الروضة. •

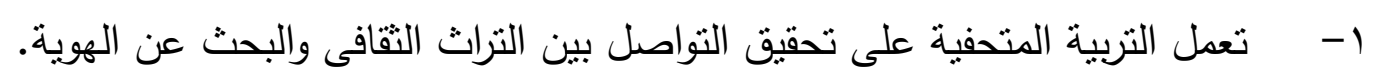

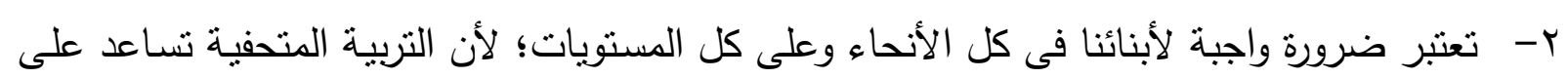
تحقيق الاستثمار النقافى والسلوكى المتميز ذو الفوائد المتعددة وقليلة التكاليف. 
(Dennis Kamel, 2005: 292)

r- تعمل التربية المتحفية على إثباع حاجات الزائر نحو السعى إلى المعرفة وإلى تتمية طاقاته الاجتماعية والتقافية عن طريق إعداد البرامج والخطط الإرشادية .

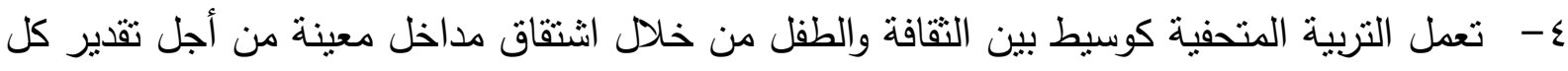
من الطفل وموضوع الدراسة حق قدره. 0- تعمل التربية المتحفية على تقوية شعور الطفل بأصله والمبراث الثقافى لبلاده. (Carol , Jan, 1998:32)

وقد أكدت العديد من الدراسات آيضاً على أهية التربية المتحفية ودورها التعليمى والتتقيفى للطفل ، التهاء فأوضحت دراسة سناء على محمد السيد( \& . . ب) أن التربية المتحفية تعتبر من أهم سبل التنشئة

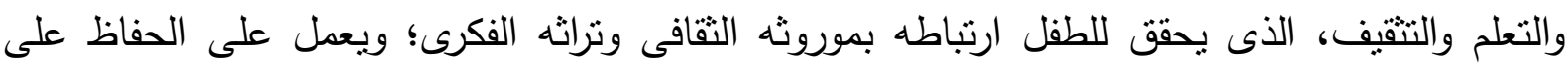

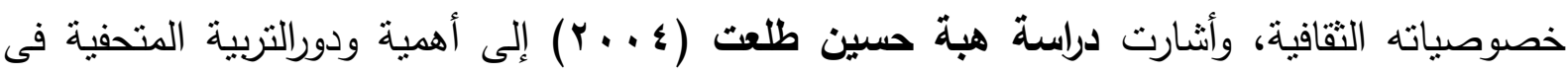

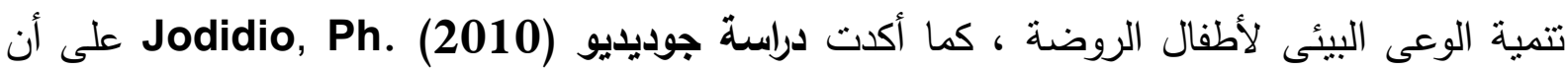
من أهم أهداف التربية المتحفية تتمية المواطنة لدى الأطفال وكانت دراسة نظرية.

\section{• دور المعلمة فى تبسيط مفاهيم وأنشطة التربية المتحفية لطقل الحضانة:}

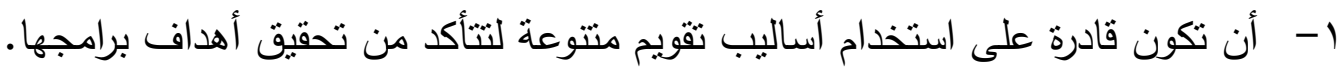

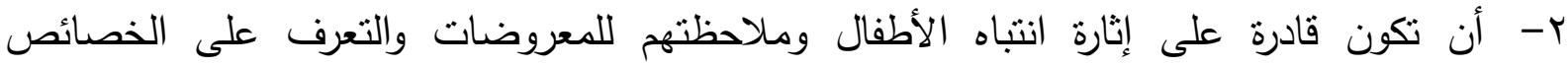
والمميزات والأنواع ووظائف المعروضات. r- أن نقوم بمناقثنة الأطفال قبل الزيارة وأثناء تجولهم ومشاهدتهم للمعروضات والتعليق عليها وعقد

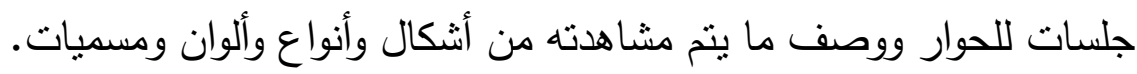

ع - أن تكون قادرة على استخدام نشاط الطفل الذاتى بممارسة الأنشطة المنتوعة والتدريبات المختلفة..

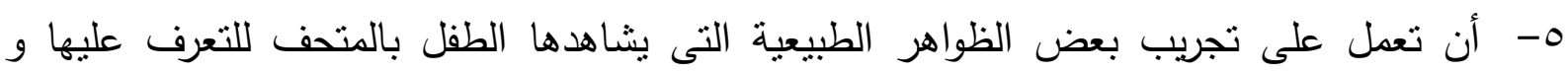
تجريب بعض الحرف التى يستطيع الطفل ممارستها من خلال الأنشطة المتتوعة التى تقدم إليه. 7- أن تهتم بإعداد الأنشطة العلمية والألعاب التزبوية التى تعتمد على مهارات الملاحظة والاستقصاء

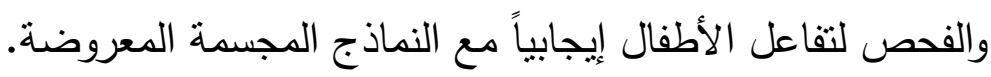
- V أن تركز اهتمامها بالأنشطة النى تعتمد على حواس الأطفال حيث أنها المدخل للتعلم والمعرفة.

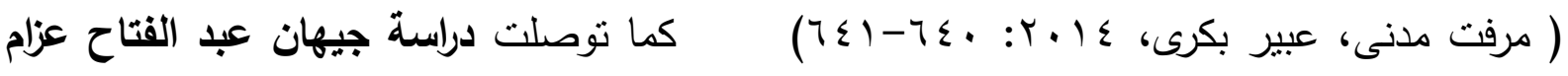

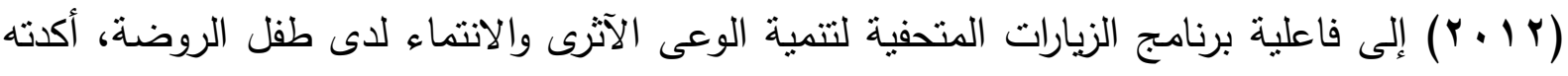

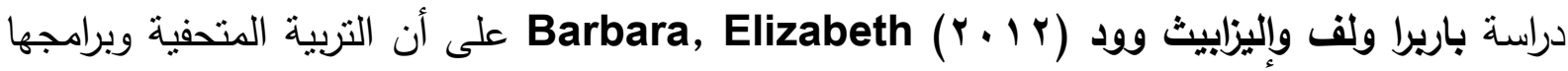
لها تأثير فعال على نمو بعض السلوكيات الإيجابية لأطفال ما قبل المدرسة.أكدت دراسة عبير بكرى 
فراج، مرفت سيد مدنى شاذلى (ع ب ب) على دور التربية المتحفية فى تتمية بعض المفاهيم التاريخية والجغرافية لطفل الروضة فى ضوء معايير الجودة.

\section{المحور الثانى - المفاهيم الحضارية لمصر الفرعونية:}

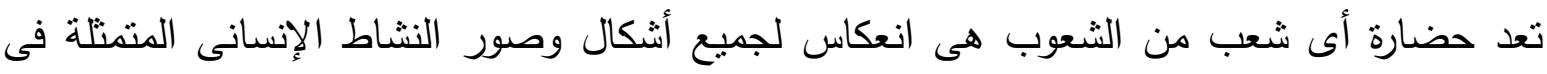

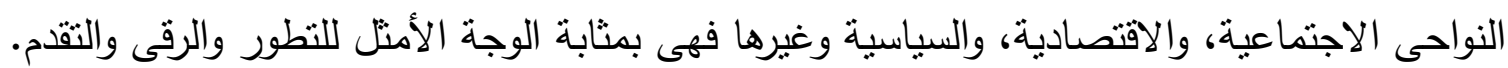
حضارة مصر الفرعونية: حكم الفراعنة مصر حوالى أكثر من .... آلاف سنة وتعبر هذه الحضارة هى بداية العصور التاريخية لمصر ، ويبدأ العصر الفرعونى بالعصر العتيق حيث حكم فيه هيه مينا موحِّ القطرين ، ثم جاء عصر الدولة القديمة الذى أطلق عليه "عصر بناة الأهرام" الذى شيدت فيه

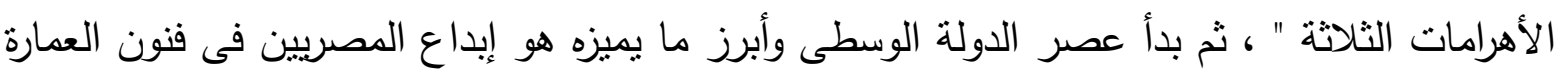

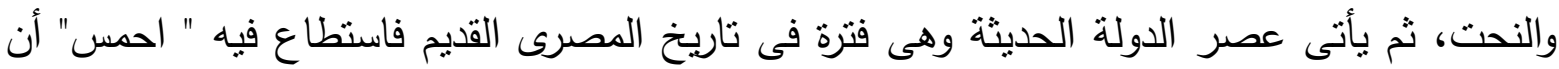

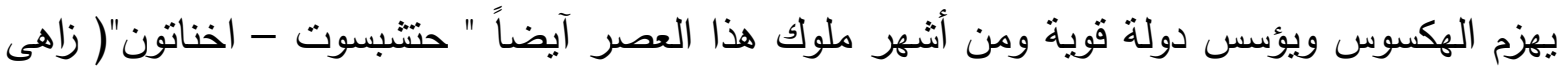

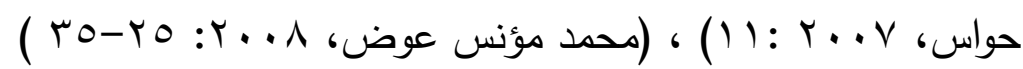
تعريف المفاهيم الحضارية:

يعرف (أحمد حسين اللقانى، وآخرون، ب99 19: r7 1) المفاهيم بأنها " إحدى جوانب التعلم والتى من خلالها يتم تجميع الحقائق والمعلومات، وإعادة تتظيمها بحيث تثترك فيما بينها بصفات جوهرية تتدرج فى لتى فئات لها معنى، لذا أصبح من الضرورى الاهتمام بتعلم المفاهيم للحد من تراكم الحقائق والمعلومات ومواجهة التزايد المستمر فيها".

ويعرف (ول ديورانت) صاحب ( قصة العضارة): الحضارة بأنها " نظام اجتماعى يعين الإنسان على الزيادة من إنتاجه الثقافى، وإنما تتألف الحضارة من عناصر أربعة هى: الموارد الاقتصادية، والنظم

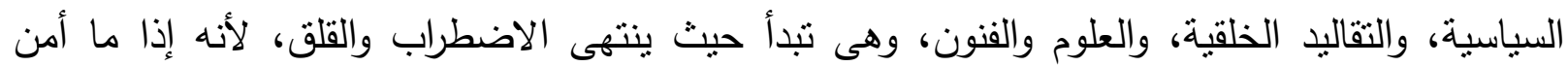

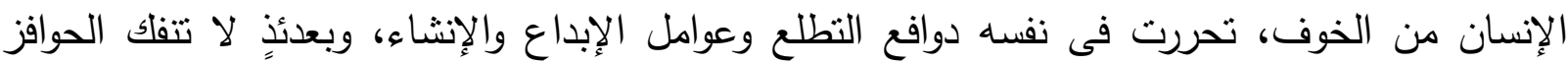
الطبيعية نستتهضه للمضى في طريقه إلى فهم الحياة وازدهارها".

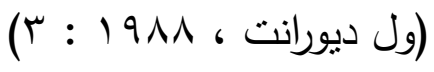

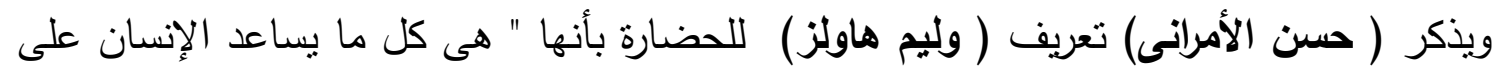

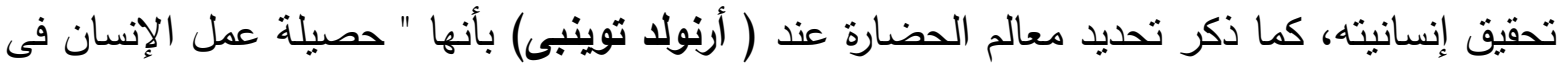

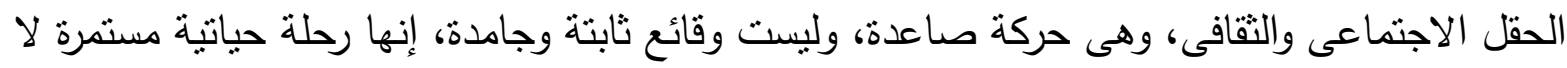

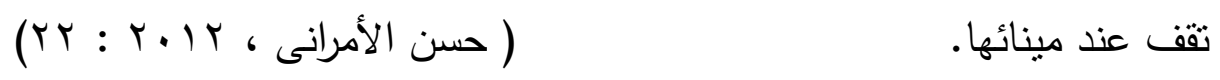
وضوء ما سبق تعرف الباحثة المفاهيم الحضارية إجرائياً بإنها " إكساب الطفل مجموعة من الحبان : الحقائق،

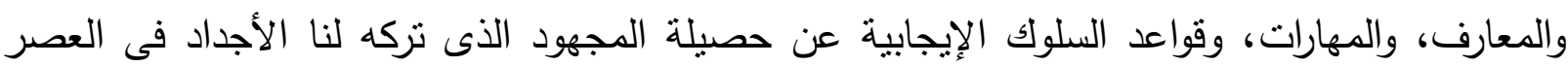


الفرعونى؛ لإقامة حضارة مصرية عريقة، وتبسيط أبرز ما يميز تلك العصر من نظم سياسية، وموارد اقتصادية، وتقاليد خلقية وعبادات دينية، وعلوم وفنون حضارية". وقد هدفت دراسة دوج كى Doug,K (2009) إلى تعريف الأطفال بحضارات العالم القديم واقتصرت على حضارة بلاد ما بين النهرين - حضارة مصر هبة النيل- حضارة الرومان)وتوصلت الدراسة

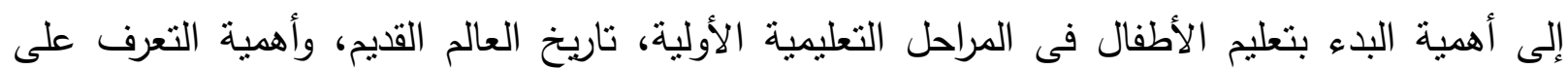

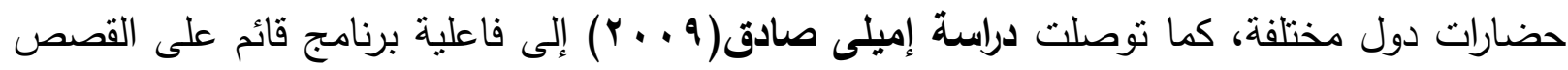
التاريخية فى إكساب طفل الروضة المعرفة بالتاريخ. • أبعاد المفاهيم الحضارية :

استتدت الباحثة عند تقسيمها للمفاهيم الحضارية لمصر الفرعونية إلى تعريف (ول ديورانت) ، حيث

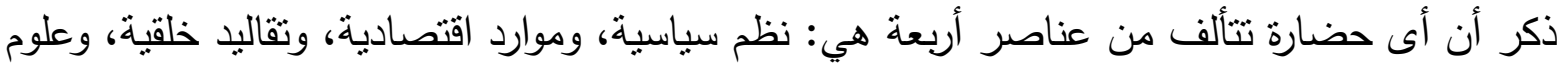

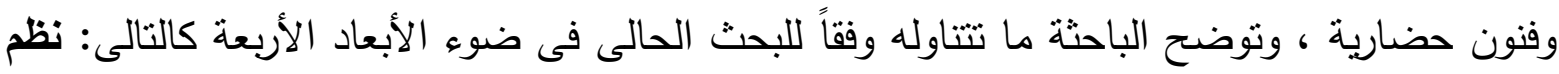
سياسية: أثنهر الملوك والحكام بمصر الفرعونية، موراد اقتصادية: نهر النيل ودوره العظيم فى قيام

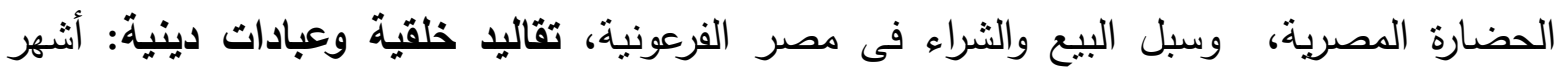
العادات والعبادات والأعياد والاحتفالات التى تميزت بها مصر الفرعونية قديماً، علوم وفنون حضارية:

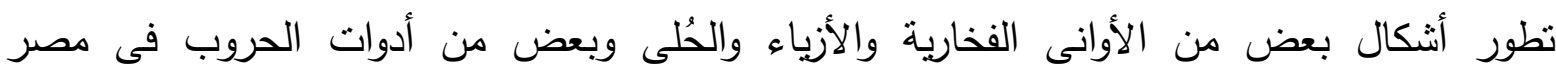

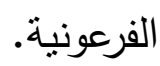

• نظم سياسية: تُعتبر مصر أول دولة فى العالم، عرفت نظام الدولة المركزية المستقرة، حيث تكوَّن

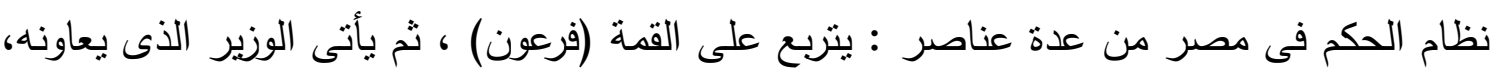

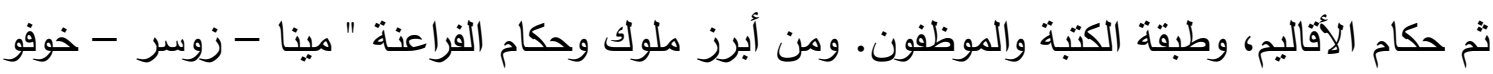

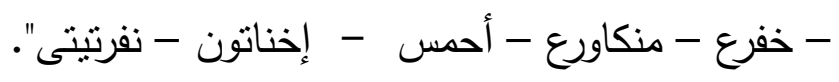

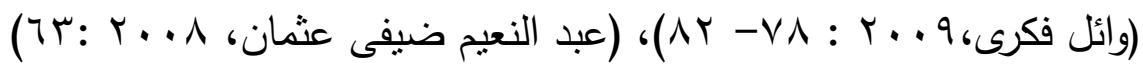

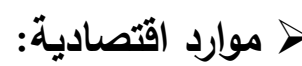

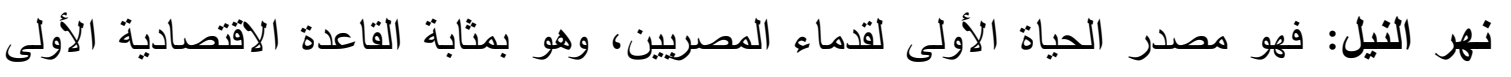

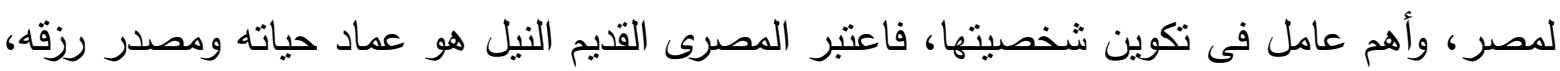
ومدبر شُؤنه، لذلك عُرفت مصر بـ"هبة النيل" فهو الأساس فى قيام الحضارة الفرعونية العريقة. (علاء

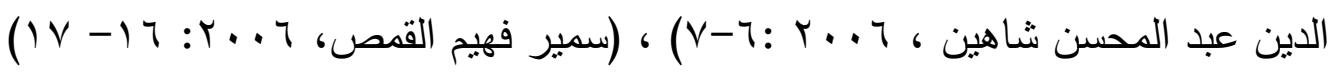

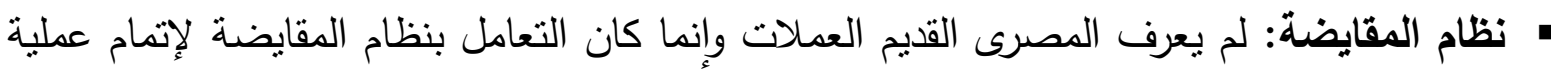

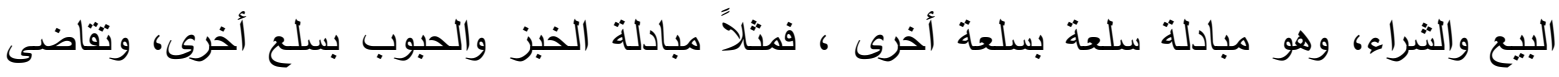

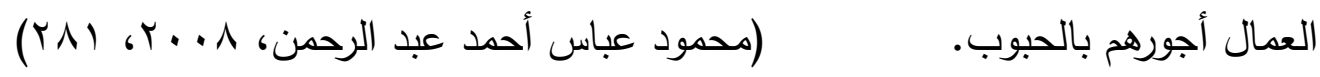


تقاليد خلقية وعبادات دينية: لعب الدين دوراًهاماً فى حياة المصريين، كما ساهم فى بناء الحضارة المصرية القديمة عن طريق غرس قيم الخير والعدالة والحق والصدق فى نفوس المصريين.(حسن محمد

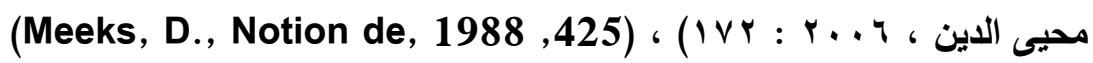
تميزت الديانة المصرية القديمة بالعديد من المميزات والخصائص ومنها:

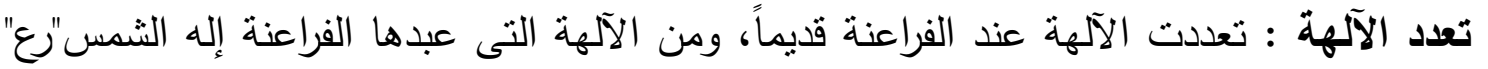
كما عبدوا البقر والقطط وفى الدولة الحديثة عبدوا آمون" نظراً لقوته وانتصاره على الهكسوس ،وبمرور الهاته

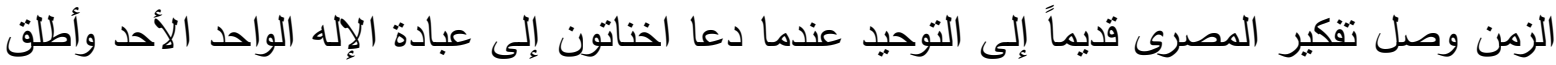

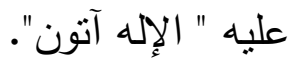

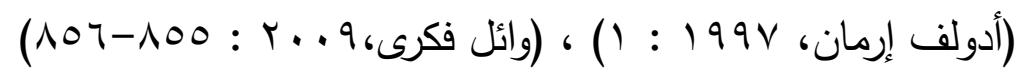

• المعبد والكاهن: المعبل: هوعبارة عن بيت الإله، فكان بمثابة المكان الذى يذهب إليه الإنسان للعبادة

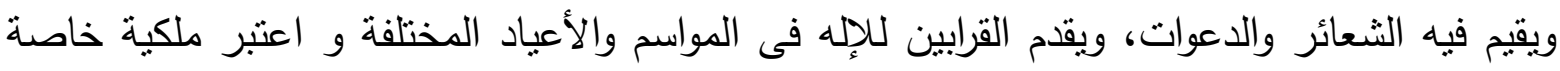

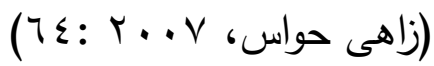
يختص بها الإله وحده. أما الكاهن الفرعونى : تعرفه الباحثة إجرائياً بأنه " هو بمثابة رجل الدين عند الفراعنة والمسئول عن إقامة الثعائر الدينية والاحتفالات ووعظ الناس وإرشادهم ،كما أنه كان يدعوهم لعباده الآله وتقيم التحية والقرابين له" . •علية التحنيط : لجأوا الفراعنة لعملية التحنيط وذلك لحفظ جثمان المتوفى لأطول فترة ممكنة بعد وفاته حتى تتعرف عليه الروح فى العالم الآخر ، وكانت تشتغرق عملية التحنيط حوالى • • يومأ، وتبدأ

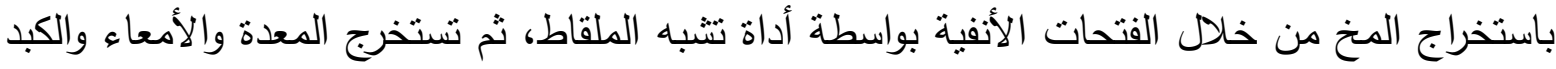
والرئتان من خلال فتحة فى الجنب لتوضع بداخل أوان، ثم بعد ذلك يغطى الجسم كله بملح النطرون

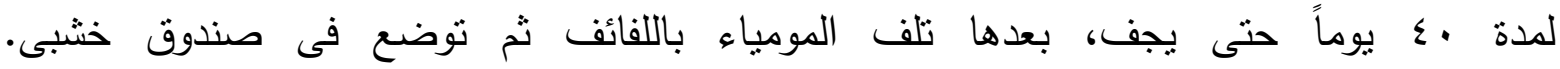

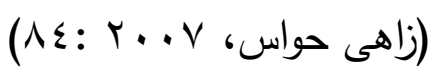

عادات وتقاليد فرعونية : ومن أثنهر الأعياد والاحتفالات عند الفراعنة "عيد شم النسيم " كان

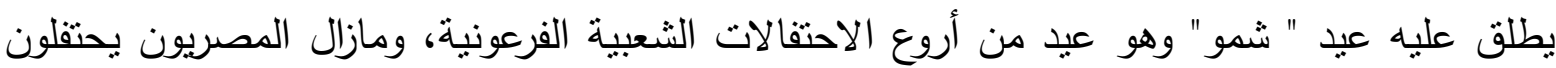

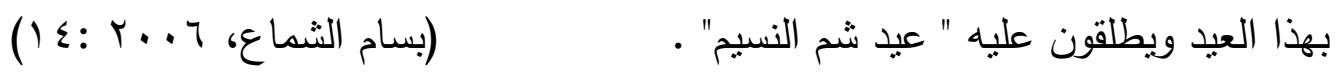
• علوم وفنون حضارية: نبغ المصر القديم فى العديد من العلوم والفنون وتتتاول الباحثة بعضاً منها كالتالى: - اللغة الهيروغليفية: كتابة مصرية قديمة استخدمها قدماء الدصريين لتنجيل الأحداث على المعالم والنصوص الدينية على جدران المعابد والمقابر وأسطح التماثيل وغيرها

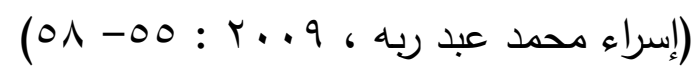
ورق البردى: وتعرفه الباحثة إجرائياً بأنه " عبارة عن ورق يُصنع من نبات طويل يسى البردى ينمو على ضفاف نهر النيل، ويتم تجفيفه نحت أثنعة الثمس للكتابة عليه". 
• الكاتب الفرعونى: وهى من المهن المرموقة فى الدولة، حيث تعتبر من أهم المهن فى مصر

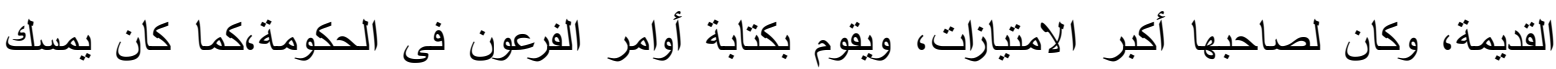

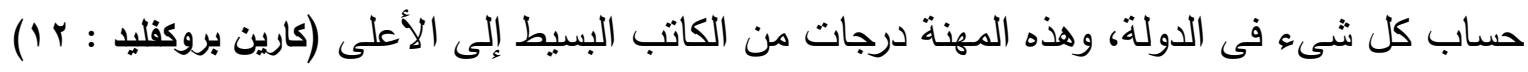

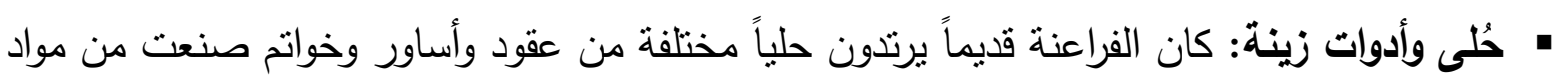

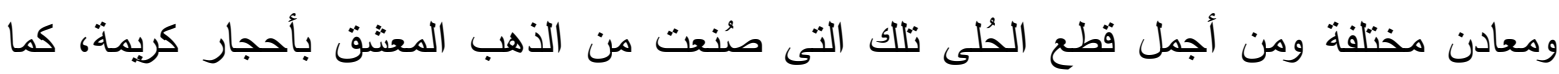

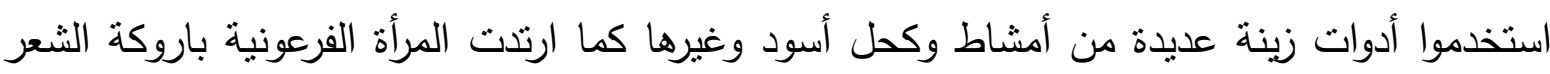

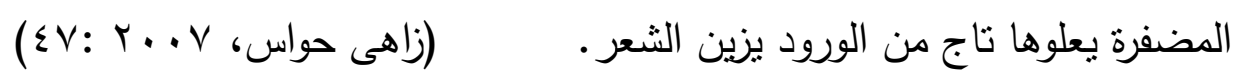

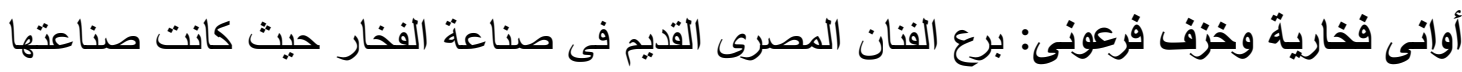
منتشرة منذ آلاف السنين، كما ادى احتياج المصرى القديم للأدوات الفخارية لطهي الطعام وحفظ المياه http://ar.wikipedia.org/wiki وغيره. - و

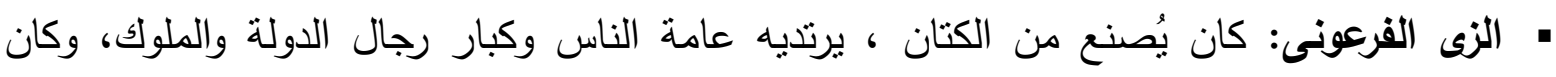

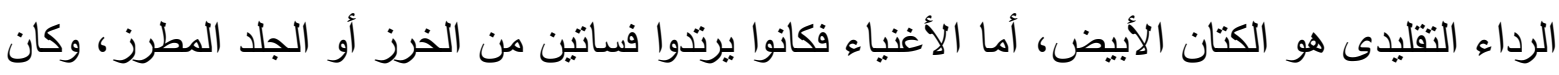

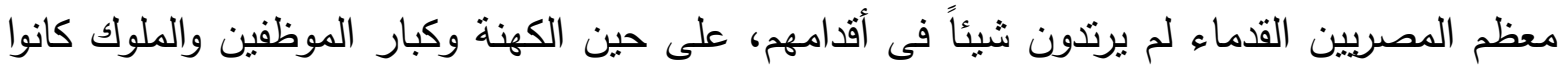

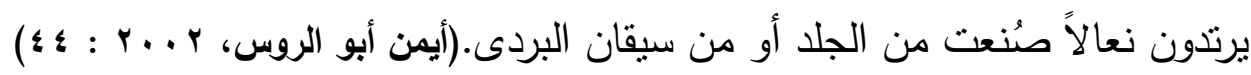

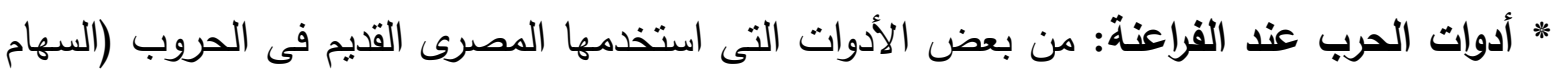

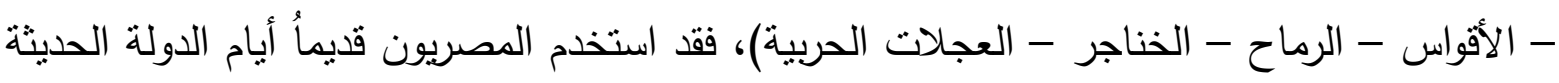

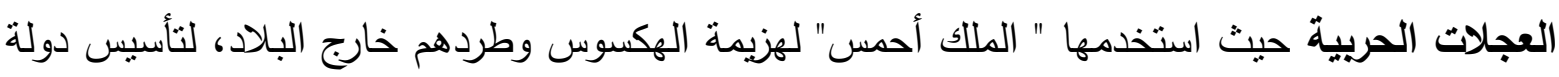

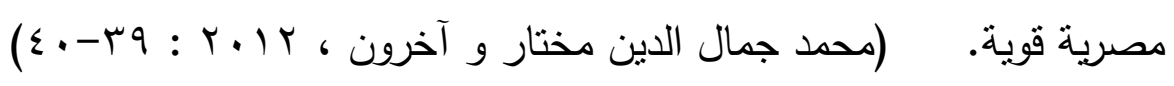

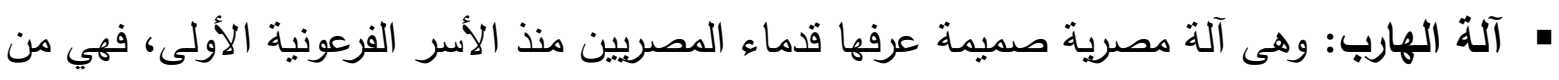

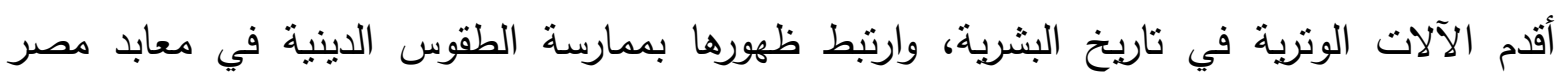

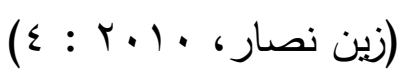

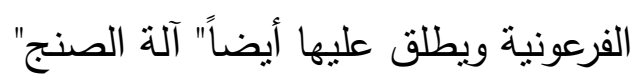
وترى الباحثة أن من أنسب المتاحف التى تتلاءم مع طبيبعة البحث الحالى، وتعبر عن الحضارة

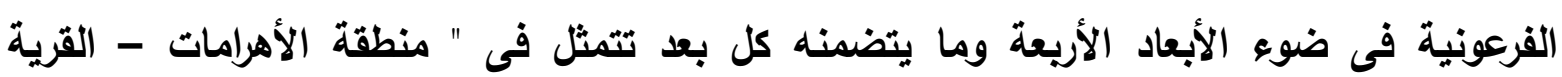
الفرعونية - المتحف المصرى". • دور المعلمة فى تنمية بعض المفاهيم الحضارية لمصر الفرعونية لطفل الحضانة:

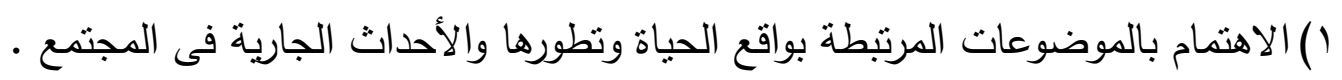

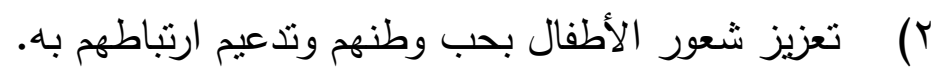

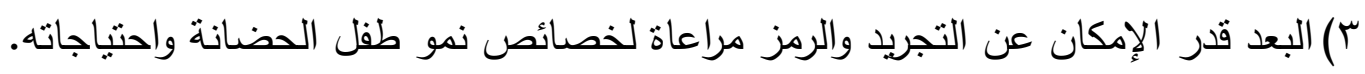
ع) التركيز على القدوة والنماذج البارزة فى الوطن، كى يندمج معها الأطفال ويقلدوها. 0) خلق الإحساس بجمال الوطن والتأكيد على المحافظة على البيئة ونظافتها. 
7) تدعيم شعور الاعتزاز بالآثار الحضارية التى خلفها الأجداد عبر العصور . V) التأكد من ممارسة الطفل لقيم المواطنة التى يتعلمها منل التعاون والمشاركة والحرية والتعبير عن الآراء

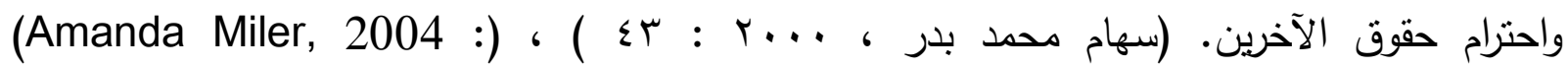

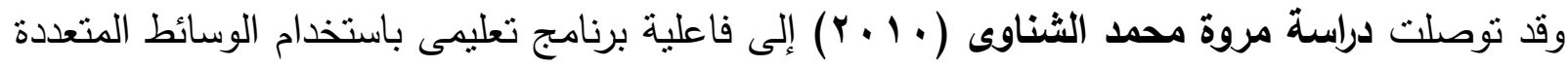
لإكساب طفل الروضة بعض المفاهيم التاريخية المتضمنة بالحضارة المصرية قديماً وحديثاً، كما أكدت دراسة إيمان سعد السيد(Y l • Y ) على أهمية استخدام أدب الطفل وفاعليته فى تتمية الوعى بالتاريخ القومى لدى طفل الروضة فى ضوء المعايير القومية لرياض الأطفال، كما نوصلت دراسة أسماء إسماعيل أحمد (Y Y • Y إلى فاعلية برنامج كمبيوترى متعدد الوسائط تفاعلى لإكساب بعض المفاهيم التاريخية لطفل الروضة. خطوات البحث وإجراءاته: منهج البحث : استخدت الباحثة المنهج شبه التجريبي لتطبيق أنشطة البرنامج على مجموعة تجربيية مع وجود مجموعة أخرى ضابطة وعمل قياس قبلي وبعدى للمجموعتين ومقارنة النتائج بالنسبة للمجموعة التجربيية والضابطة، للتعرف على فاعلية البرنامج. مجتمع وعينه البحث : يتمثل مجتمع البحث الحالى فى جميع أطفال دور الحضانة بمحافظة الجيزة، وقد تم اختيار حضانة التوحيد بالجيزة بالطريقة العدية، ويرجع اختيارها للتقارب بين المستوى الإجتماعى والإقتصادى للأطفال، بالإضافة إلى تعاون إدارة الحضانة مع الباحثة فى تتفيذ البحث،وكذلك ملاعمة

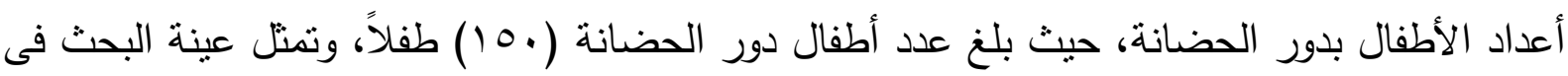
أطفال الحضانة من (r-乏) سنوات، وقد نم اختيارهم بالطريقة العشوائية، والبالغ عددهم (• ع) طفلاً وطفلة، تم تقسيمه إلى مجموعنين المجموعة التجريبية وعددها (·r) عشرون ومجموعة أخرى ضابطة وعددها ( • ( ) عشرون.

*التحقق من التكافؤ بين بين عينة البحث (الضابطة والتجريبية ): قامت الباحثة بإيجاد دلالة الفروق بين متوسطات درجات أفراد المجموعتين التجريبية والضابطة فى القياس القبلى من حيث بعض المفاهيم الحضارية لمصر الفرعونية كما يوضحها الجدول التالى: 
جدول ( ) دلالة الفروق بين متوسطات درجات أفراد المجموعتين التجريبية و الضابطة من حيث

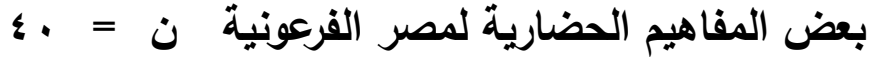

\begin{tabular}{|c|c|c|c|c|c|c|c|}
\hline \multirow[t]{2}{*}{ اتجاه الدلالة } & \multirow[t]{2}{*}{ مستوى } & \multirow[t]{2}{*}{$ت$} & \multicolumn{2}{|c|}{ المجموعة الضابطة } & \multicolumn{2}{|c|}{ المجموعة التجريبية } & \multirow[t]{2}{*}{ المتغيرات } \\
\hline & & & $r \varepsilon$ & $r_{p}$ & $1 \varepsilon$ & p & \\
\hline- & غير دالة & $1, \mathrm{v}$ & $\varepsilon, r$ & 01,1 & $\varepsilon, r$ & $\varepsilon q, Y$ & الحقائق والمعارف \\
\hline- & غير دالة & $1,1 r$ & $r, q$ & $r \wedge, 0$ & $r, r$ & $r V, T$ & المهارات \\
\hline & غير دالة & אוזו, & $r, v$ & $r \otimes, \wedge$ & $r, 1$ & $r_{0, r}$ & قواعد السلوك \\
\hline- & غير دالة & $1,0 \cdot 1$ & $\Lambda, r$ & $1.0,0$ & $\wedge, \wedge \vee$ & I.r,Y & الارجة الكلية \\
\hline
\end{tabular}

يتضح من جدول (1) عدم وجود فروق دالة إحصائية بين متوسطات درجات أفراد المجموعتين التجريبية والضابطة فى القياس القبلى على المقياس المصور ؛ مما يثير إلى تكافؤ المجموعتين .

"التحقق من التجانس بين أفراد عينة البحث: قامت الباحثة بإيجاد دلالة الفروق بين متوسطات درجات عينة البحث فى القياس القبلى من حيث مقياس بعض الدفاهيم الحضارية لمصر الفرعونية. جدول (ץ) دلالة الفروق بين متوسطات درجات افراد عينة البحث من حيث بعض الفئ المفاهيم الحضارية

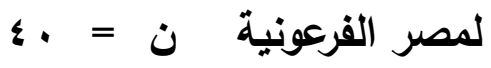

\begin{tabular}{|c|c|c|c|}
\hline اتجاه اللالالة & مستوى الالالة & كاr & المتغيرات \\
\hline - & غير دالة & 11 & الحقائق والمعارف \\
\hline- & غير دالة & $1 \%, 1$ & المهارات \\
\hline- & غير دالة & $r, r$ & قواعد السلوك \\
\hline- & غير دالة & $\checkmark, \wedge$ & الارجة الكلية \\
\hline
\end{tabular}

يتضح من جدول (Y) عدم وجود فروق دالة إحصائية بين متوسطات درجات أفراد العينة فى القياس القبلى على مقياس بعض المفاهيم الحضارية لمصر الفرعونية مما يشير الى تجانس أفراد عينة البحث.

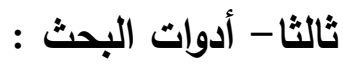

1- مقياس بعض المفاهيم الحضارية لمصر الفرعونية المصور لطفل الحضانة. ( إعداد/ الباحثة) 1- برنامج التزبية المتحفية لتتمية بعض الدفاهيم الحضارية لمصر الفرعونية. (إعداد/ الباحثة) 
1- مقياس بعض المفاهيم الحضارية لمصر الفرعونية المصور: ( إعداد الباحثة) أ- الههف من المقياس: يهذف هذا المقياس إلى قياس بعض المفاهيم الحضارية لهصر الفرعونية من (ب-ع) لطفل الحضانة. ب- ت خطوات تصميم المقياس:

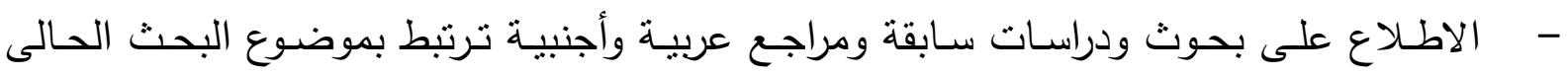
للاستفادة منها فى إعداد المقياس وبنوده . - عرض المقياس على مجموعة من الأساتذة المحكمين للتأكد من صلاحيته قبل التطبيق واحتوت

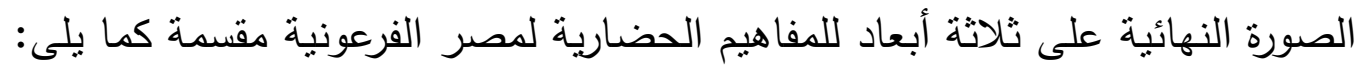

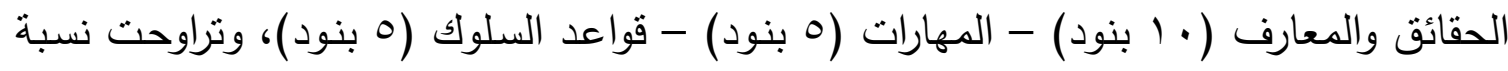

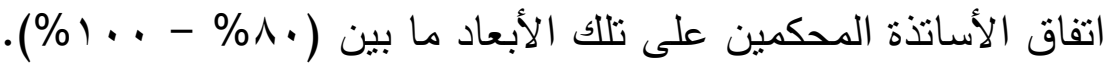

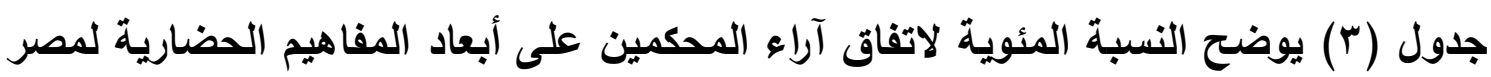
الفرعونية أواء المحين

\begin{tabular}{|c|c|c|}
\hline النسبة المئوية & الابعاد & 5 \\
\hline$\% 9$. & الحقائق والمعارف & -1 \\
\hline$\% 1 \ldots$ & المهارات & $-r$ \\
\hline$\% q$. & قواعد السلوك & $-\mu$ \\
\hline
\end{tabular}

ج- وصف المقياس: احتوى المقياس على ثلاثة أبعاد رئيسية مقسة كالتالى: 1 - حقائق ومعارف: يعنى بها تلك المعلومات الحضارية التى ينوصل إليها الطفل من خلاد الملاحظة المبانشرة المنظمة أو التفاعل الإيجابى الملائم مع المعروضات مع مع ممارسة الأنثطة النطبيقية المتحفية

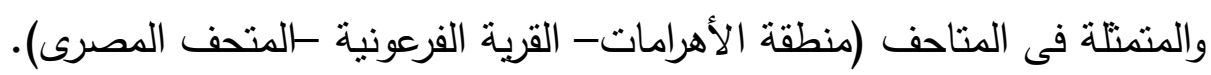
ץ- مهارات: يعنى القدرة على القيام بعمليات الملاحظة والتصنيف وإدراك العلاقات والتمييز بين الأثياء تبعاً لشكلها أو استخداماتها بإتقان. ب- قواعد السلوك : يعنى بها السلوكيات الإيجابية والسلبية التى يمارسها الطفل تجاه وطنه وتجاه الآثار

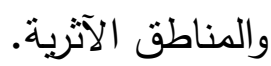

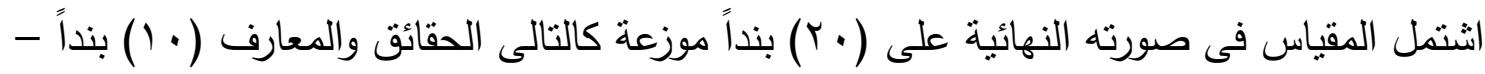

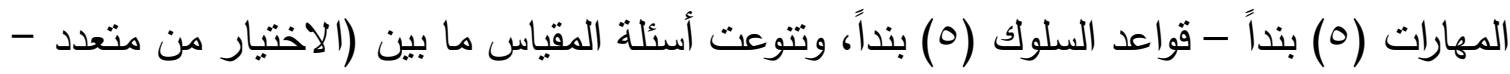
تلوين الشكل- توصيل - ترتيب مراحل - وضع علامة صح أو خطأ).

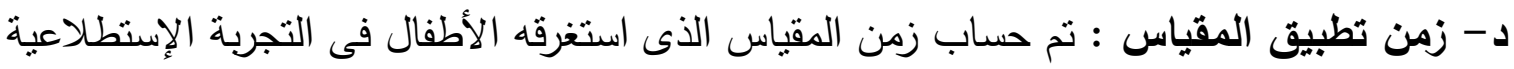
على أساس متوسط زمن إجابات الأطفال ، على الاختبار باستخدام المعادلة التالية: 
متوسط زمن المقياس: متوسط زمن أسرع طفل فى الإجابة+ منوسط زمن أبطأ طفل فى الإجابة

\section{r}

وقد توصلت الباحثة إلى أن زمن مقياس المفاهيم الحضارية لمصر الفرعونية هو 10 دقيقة. ج- تعليمات المقياس: تعرض الباحثة الصور المكونة لكل سؤال على الطفل مع نوجيه لونيه الأسئلة والاختيارات بصوت واضح وباللغة العامية، وتتطلب من الطفل اختيار اجابة واحدة على كل سؤال.

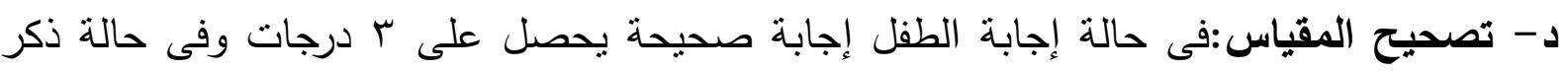

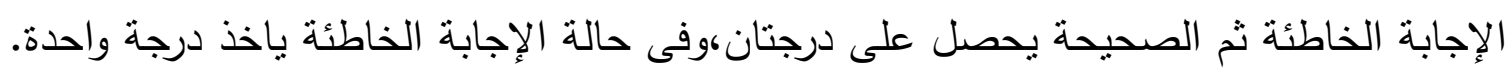

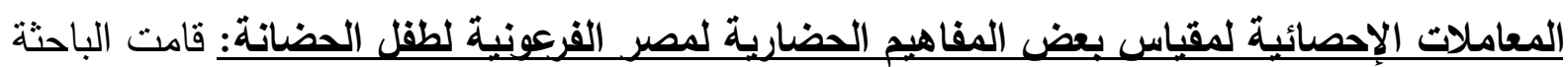
بايجاد معاملات الصدق و الثبات للمقياس وذللك على عينة قوامها ـ ب طفلاً. أولاً: معاملات الصدق معادلات الصناد اعتمدت الباحثة على إيجاد معاملات الصدق لأبعاد المقياس على صدق المحكمين والصدق العاملى . صدق المحكمين

قامت الباحثة بعرض المقياس على عدد من الخبراء المتخصصين فى المجالات التربوية والنفسية، و

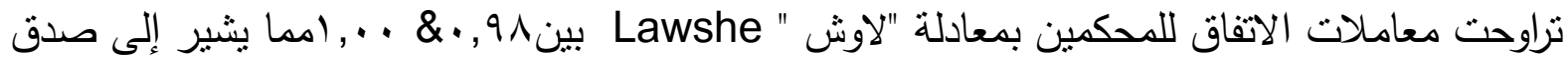

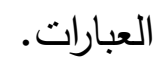

\section{الصدق العاملي لمقياس بعض المفاهيم الحضارية لمصر الفرعونية لطقل الحضانة :}

نم إجراء التحليل العاملي على عينة مؤلفة من (•ـ ) طفلا، بتحليل المكونات الأساسية للمقياس بطريقة

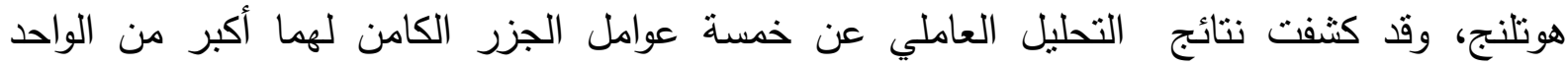

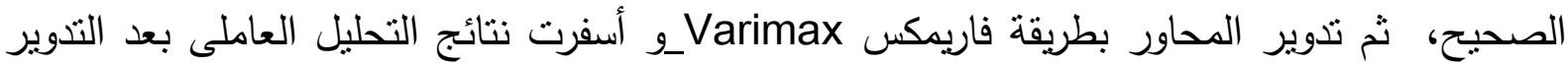

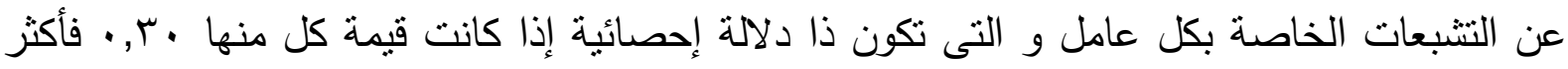
على محك كايزر ، و ذللك كما يوضحها الجدول التالى: 
جدول (؛ ) نتائج التحليل العاملي بعد تدوير المحاور

\begin{tabular}{|c|c|c|c|c|c|}
\hline التشبعات & (قواعد السلوك) & التشبعات & ( رقم العبارة & التشبعات & رقم العبارة( الحقائق \\
\hline • & 19 & $\cdot, \leqslant 4$ & 11 & $\cdot, \leqslant 1$ & 1 \\
\hline$\cdot, r \leq$ & IV & $\cdot, \leqslant 0$ & Ir & $\cdot, \varepsilon r$ & r \\
\hline r & 11 & $\cdot, \leqslant 0$ & ir & $\cdot, \leqslant \mu$ & $r$ \\
\hline$\cdot, r o$ & 19 & •, $\leqslant$ \& & $1 \varepsilon$ & $\cdot, \varepsilon \varepsilon$ & $\varepsilon$ \\
\hline \multirow[t]{6}{*}{$\cdot, r r$} & $r$. & • , & 10 & $\cdot, \leqslant 0$ & 0 \\
\hline & & & & $\cdot, \leqslant r$ & 7 \\
\hline & & & & $\cdot, \leqslant 1$ & v \\
\hline & & & & $\cdot, \leqslant 0$ & $\wedge$ \\
\hline & & & & $\cdot, \leqslant r$ & 9 \\
\hline & & & & $\cdot, \varepsilon r$ & 1. \\
\hline $1,0 \leq$ & الجزر الكامن & $r, 71$ & الجزر الكامن & $0, \wedge \mu$ & الجزر الكامن \\
\hline
\end{tabular}

يتضح من جدول ( ع ) أن التشبعات الخاصة بكل عامل من معاملات كل بند من بنود المقياس دالة إحصائياً حيث قيمة كل منها أكبر من ( • ب, • ) على محك جيلفورد مما يدل على صدق المقياس. ثانياً : معاملات الثبات

اعتمدت الباحثة على إيجاد معاملات الثبات لأبعاد بعض المفاهيم الحضارية لمصر الفرعونية لطفل الحضانة بإيجاد معامل الفا بطريقة كرونباخ و طريقة اعادة تطبيق الاختبار وذللك على عينة قوامها ـ ع

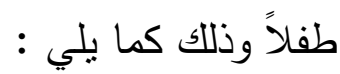
ا - معامل الثبات ( ألفا) بطربقة كرونباخ

قامت الباحثة بايجاد معاملات الثبات لأبعاد المقياس و للمقياس ككل كما يتضح فى جدول ( •)

\begin{tabular}{|c|c|c|}
\hline \multirow[t]{5}{*}{ ن } & معامل الثبات ( ألفا) & الأبعاد \\
\hline & $\cdot, \wedge 9$ & الحقائق والمعارف \\
\hline & $\cdot, \wedge 1$ & المهارات \\
\hline & $\cdot, \wedge r$ & قواعد السلوك \\
\hline & $\cdot, \wedge \leqslant$ & الارجة الكلية \\
\hline
\end{tabular}

يتضح من جدول ( 0) إن قيم معاملات الثبات مرتفعة مما يدل على ثبات المقياس

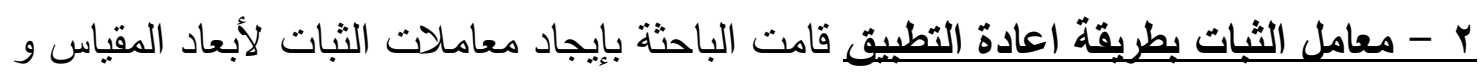
للمقياس ككل بطريقة إعادة التطبيق بفاصل زمنى قدره شهر كما يتضح فى جدول (†) 


\begin{tabular}{|c|c|}
\hline معامل الثبات & الأبعاد \\
\hline$\cdot, 90$ & الحقائق والمعارف \\
\hline$\cdot, 9 \leq$ & - - المهارات \\
\hline., $9 r$ & - - قواعد السلوك \\
\hline •, & الارجة الكلية \\
\hline
\end{tabular}

يتضح من جدول (T ) إن قيم معاملات الثبات مرتفعة مما يدل على ثبات المقياس

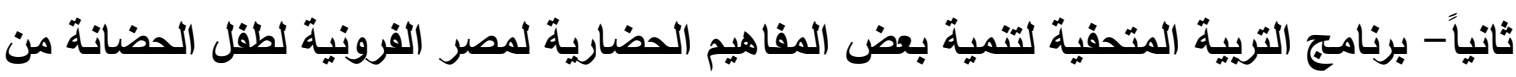

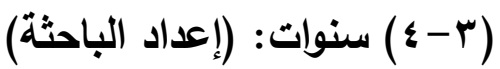
أ ـ الفلسفة العامة للبرنامج : تثتنق الباحثة فلسفة البرنامج من الآتى :

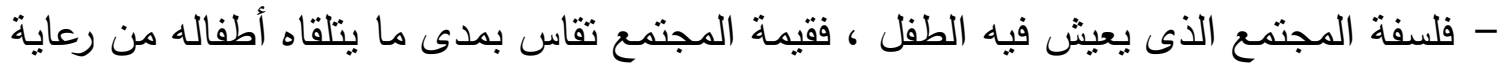
وتوجيه، مما يوفر لهم حياة ناجحة غنية بالخبرات التى تساعدهم فى بناء مجتمعهم.

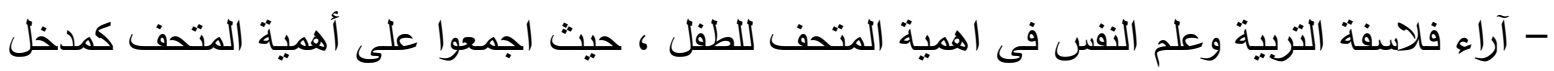

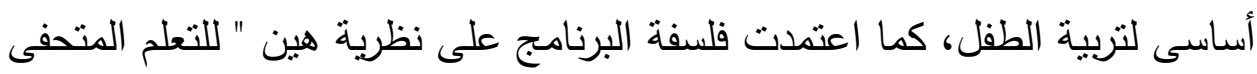

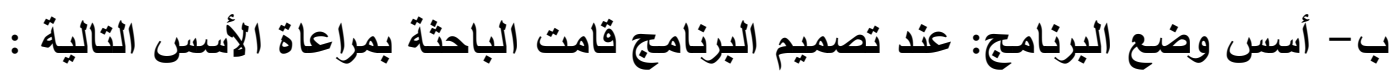

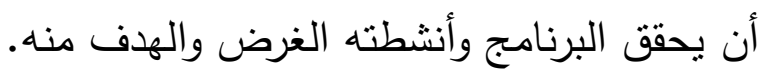
• أن تنتاسب محتويات البرنامج مع خصائص نمو الطفل وتتتاسب مع ميوله وقدراته واحيتاجاته. أن يحتوى البرنامج على أنشطة جماعية تعاونية بين الأطفال.

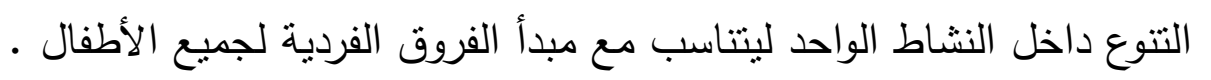
ج- خطوات إعداد البرنامج: 1- تحديد الأهداف التربوية العامة والأجرائية لبرنامج التربية المتحفية : التى تهدف فى النهاية الى تتمية بعض المفاهيم الحضارية لمصر الفرعونية لاى طف الحضانة من (r- ؟) سنوات.

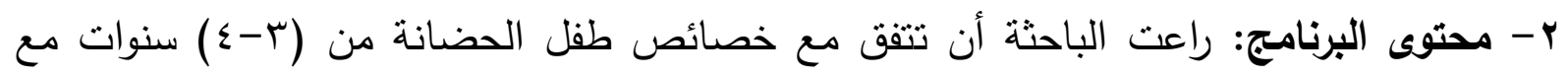

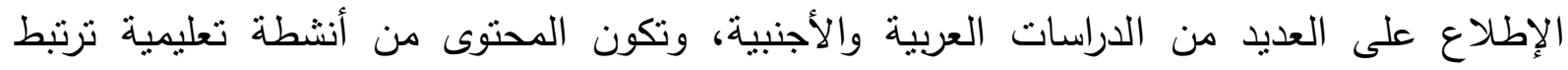

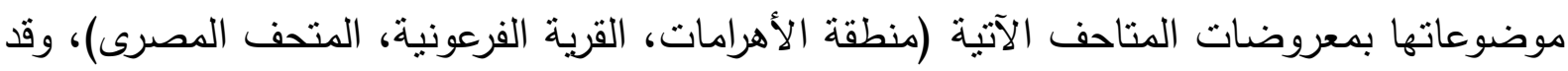

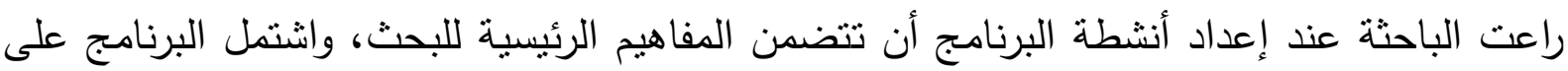

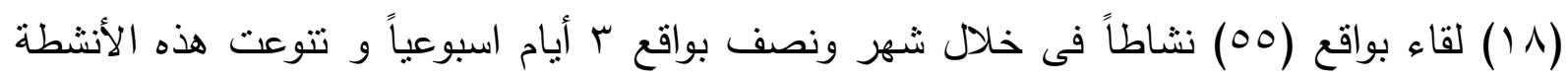

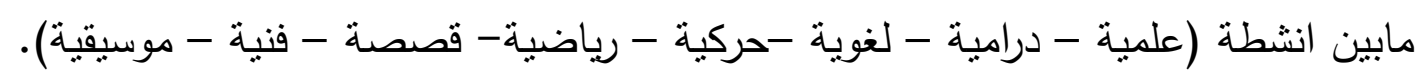

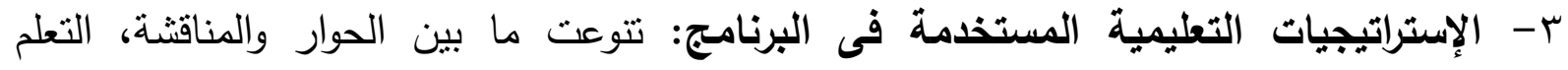

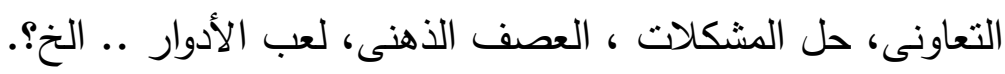


ع - الأدوات والوسائل المستخدمة فى البرنامج: وقد راعت الباحثة أن تتناسب مع خصائص وقدرات الأطفال، واستعانت بالأفلام الوثائقية والمجسمات، والطين الأسوانى و قصص مصورة وعرائس قفازية، وخرز وترتر وغيرها من الأدوات.

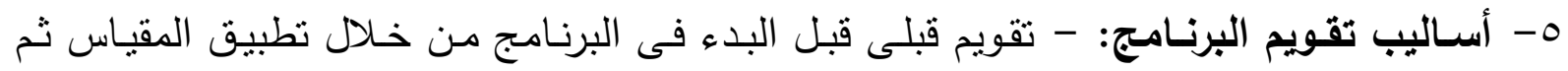
التقويم الذى يعقب كل نشاط تعليمى، واخيراً التقويم البعدى بإعادة تطبيق المقياس .

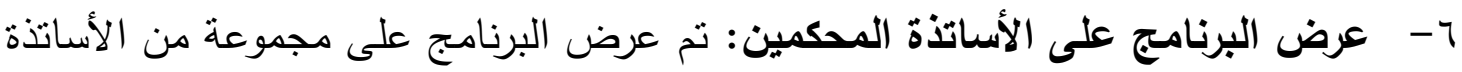

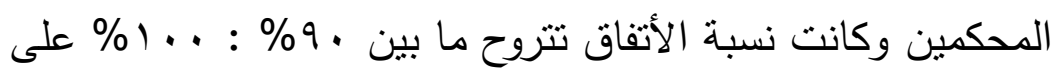
• عرض نتائج البحث وتفمبرها: الفرض الأول

توجد فروق ذات دلالة إحصائية بين منوسطات درجات أطفال المجوعة التجريبية المجموعة الضابطة

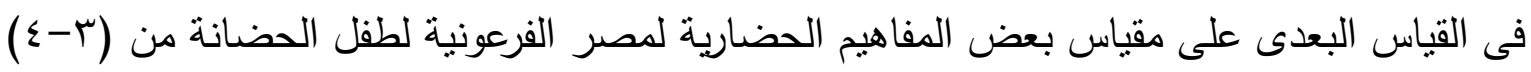
سنوات لصالح المجموعة التجريبية. و للتحقق من صحة الفرض استخدمت الباحثة اختبار " ت" لايجاد الفروق بين منوسطات درجات مجموعتين مستقلتين، كما يتضح فى جدول ( V ) ) جدول ( V الفروق بين متوسطات درجات أطفال المجموعتين التجريبية و الضابطة على مقياس بعض المفاهيم الحضارية لمصر الفرعونية ن = . ؛

\begin{tabular}{|c|c|c|c|c|c|c|c|}
\hline \multirow[t]{2}{*}{ اتجاه الدلالة } & \multirow[t]{2}{*}{ مستوى } & \multirow[t]{2}{*}{ 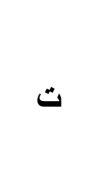 } & \multicolumn{2}{|c|}{ المجموعة الضابطة } & \multicolumn{2}{|c|}{ المحموعة التجريبية } & \multirow[t]{2}{*}{ المتغيرات } \\
\hline & & & $r \varepsilon$ & $r$ & 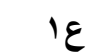 & pa & \\
\hline لصالح التجريبية & دالة عند مستوى & \& & אוז & $1 \pi, 0$ & 0,74 & $r \wedge, 0$ & وا والمعارف الحقائق \\
\hline لصالح التجريبية & دالة . . عند مستوى & ro,r & $r, \varepsilon r$ & $v, \Lambda$ & $\varepsilon, \varepsilon$ & $1 \mathrm{~T}, \mathrm{~V}$ & r- المهارات \\
\hline لصالح التجريبية & دالة, . عند مستوى & $19, r$ & $r, r$ & $v, 1$ & $r, 00$ & $1 \leqslant, 9$ & آس- قواعد \\
\hline لصايح التجريبية & دالة. . عند مستوى & $\mu_{4, V}$ & $\Lambda, r r$ & rY,O & $11, \varepsilon$ & 7,0 & الارجة الكلية \\
\hline
\end{tabular}

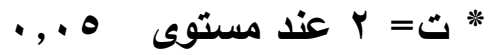

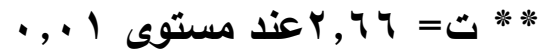


يتضح من جدول (V) وجود فروق دالة إحصائياً عند مستوى ا ., •بين متوسطات درجات أطفال كل من المجموعتين التجريبية والضابطة فى القياس البعدى بالنسبة لأبعاد مقياس بعض الدفاهيم الحضارية لكصر الفرعونية لطفل الحضانة من (r-§) سنوات لصالح المجموعة التجريبية.

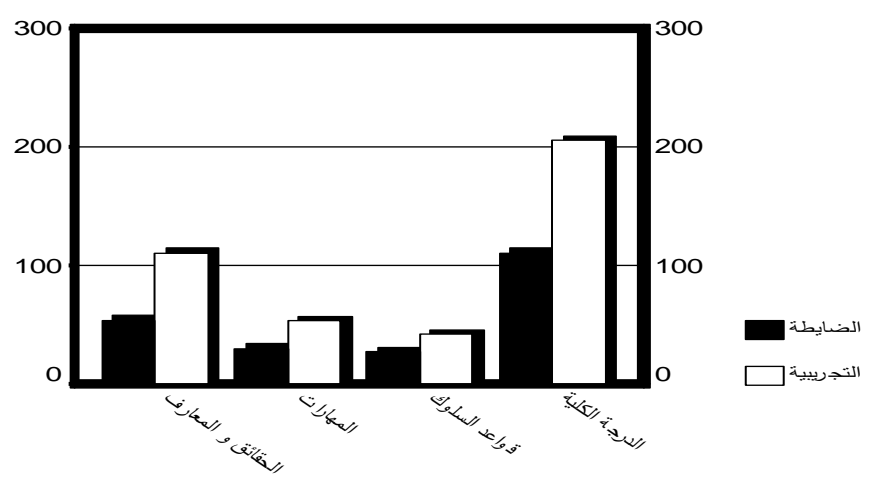

ويوضح شكل ( ) الفروق بين منوسطات درجات أطفال كل من المجموعتين التجريبية و الضابطة فى القياس البعدى على مقياس بعض المفاهيم الحضارية لمصر الفرعونية.

\section{تفسير نتيجة الفرض الأول:}

تعرض أطفال المجموعة التجريبية بدور الحضانة إلى برنامج التربية المتحفية وقيامهم بعمل بممارسة

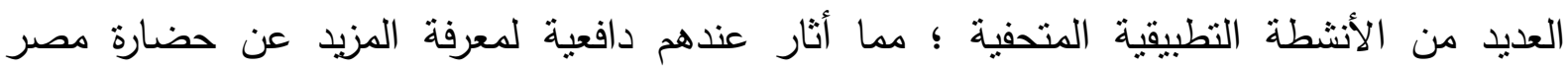

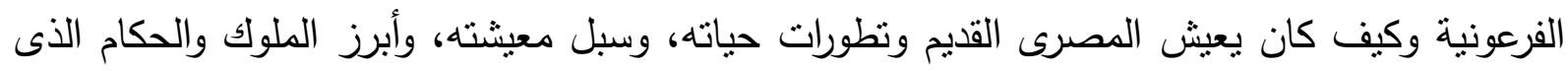
حكموا مصر ، كل ذلك ساهم فى تتمية بعض الدفاهيم الحضارية لمصر الفرعونية لدى طفل الحضانة من

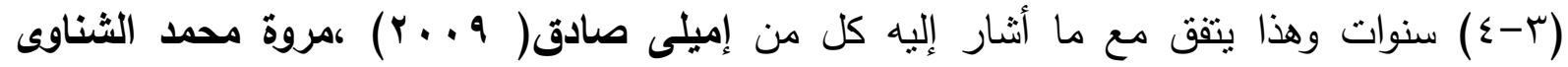

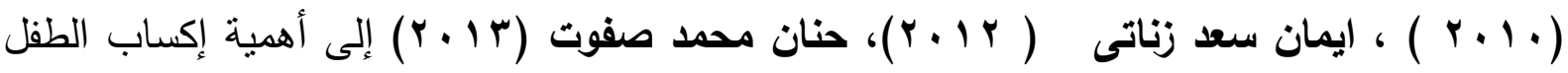

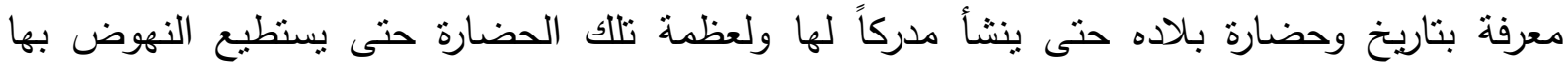
واستكمال مسيرتها نحو النطور والتغير .

الفرض الثانى: لا نوجد فروق ذات دلالة إحصائية بين متوسطات درجات أطفال المجموعة الضابطة فى لى القياسين القبلى والبعدى على مقياس بعض الدفاهيم الحضارية لدصر الفرعونية لطفل الحضانة من (r-

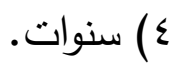


جدول (^) الفروق بين متوسطات درجات أطفال المجموعة الضابطة فى القياسين القبلى و البعدى

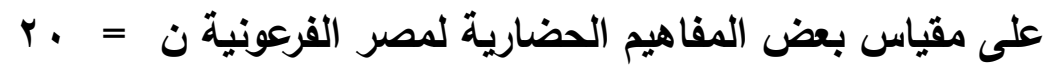

\begin{tabular}{|c|c|c|c|c|c|}
\hline \multirow[t]{2}{*}{ اتجاه الدلالة } & \multirow[t]{2}{*}{ 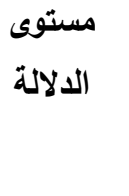 } & \multirow[t]{2}{*}{$ت$} & \multicolumn{2}{|c|}{ الفرق بين القياسين القبلى و } & \multirow[t]{2}{*}{ المتغيرات } \\
\hline & & & مج حتن & م ف & \\
\hline- & غير دالة & •, & r, צ & . & ا - الحقائق والمعارف \\
\hline- & غير دالة & $1, \pi$ & $\leqslant, 9 \leqslant$ & $1, \leqslant 4$ & المهارات \\
\hline- & غير دالة & $1,1$. & 0,1 & $1, \cdot r$ & -- ققاعد السلوك \\
\hline- & غير دالة & 1,7 & 9,74 & $r, \wedge \Gamma$ & الارجة الكلية \\
\hline
\end{tabular}

يتضح من جدول (^) عدم وجود فروق ذات دلالة إحصائية بين منتسطات درجات أطفال المجموعة الفئ الضابطة فى القياسين القبلى و البعدى مقياس بعض الدفاهيم الحضارية لمصر الفرعونية لطفل الحضانة من (r- (؟) سنوات. تفسير نتيجة الفرض الثانى: عدم تعرض أطفال المجموعة الضابطة لبرنامج التربية المتحفية، وتم الاقتصار على تعرضهم للأنشطة

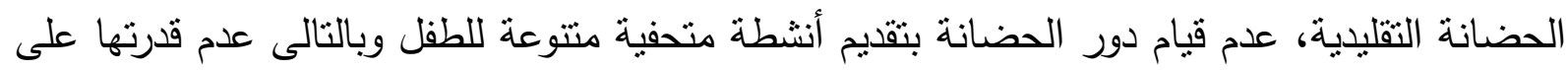

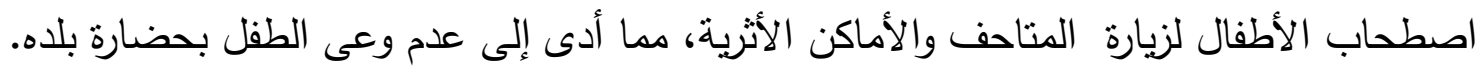

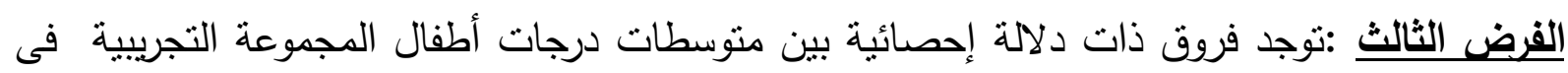

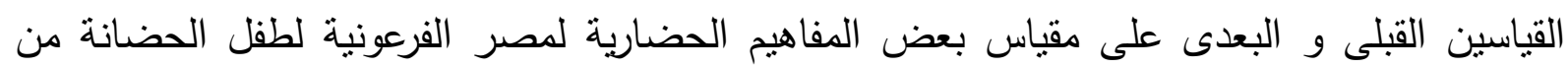

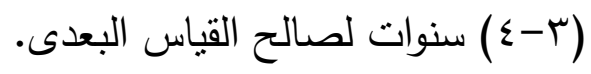
جدول ( 9 ) الفروق بين متوسطات درجات أطفال المجموعة التجريبية فى القياسين القبلى و البعدى البعى الفي

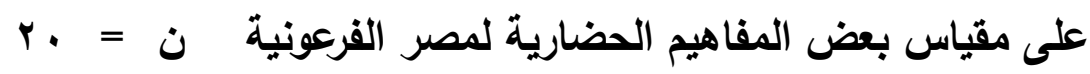

\begin{tabular}{|c|c|c|c|c|c|}
\hline \multirow[t]{2}{*}{ اتجاه الدلالة } & \multirow[t]{2}{*}{ مستوى الدلالة } & \multirow[t]{2}{*}{$ت$} & \multicolumn{2}{|c|}{ الفرق بين } & \multirow[t]{2}{*}{ المتغيرات } \\
\hline & & & مي ح ف & م ف & \\
\hline فى اتجاه القياس البعدى & دالة عند مستوى 1 ., . & $\leqslant r, \varepsilon$ & $v, 79$ & 09,7 & الحقائق والمعارف \\
\hline فى اتجاه القياس البعدى & دالة عند مستوى I +, · & $r_{0,1}$ & $0, r \wedge$ & $r \leqslant, V$ & المهارات \\
\hline فى اتجاه القياس البعدى & دالة عند مستوى 1 .,. & $11, \varepsilon$ & $\varepsilon, 74$ & $10, \mathrm{~V}$ & قواعد السلوك \\
\hline فى اتجاه القياس البعدى & دالة عند مستوى | +, • & ז & $1 \leqslant, 9$ & $1, \cdot, \cdot r$ & الدرجة الكلية \\
\hline
\end{tabular}


يتضح من جدول (9) وجود فروق دالة إحصائياً عند مسنوى ل ., · بين منوسطات درجات أطفال المجموعة التجريبية فى القياسين القبلى و البعدى على المصور فى اتجاه القياس البعدى.

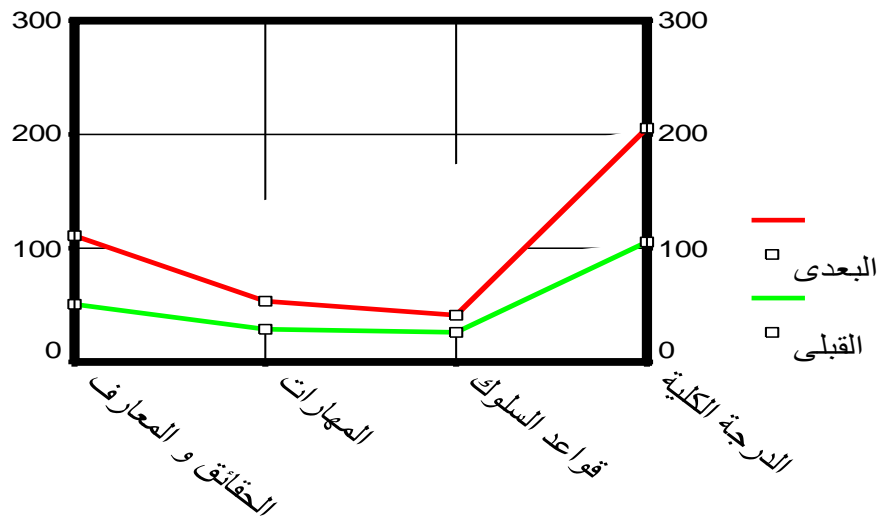

ويوضح شكل ( r ) الفروق بين منوسطات درجات أطفال المجموعة التجرييية بين القياسين القبلى و البعدى مقياس بعض الدفاهيم الحضارية لمصر الفرعونية لطفل الحضانة . تفسبر نتيجة الفرض الثالث:

ترجع الباحثة ذلك إلى تعرض أطفال المجموعة التجريبية لبرنامج التربية المتحفية وممارسة العديد من

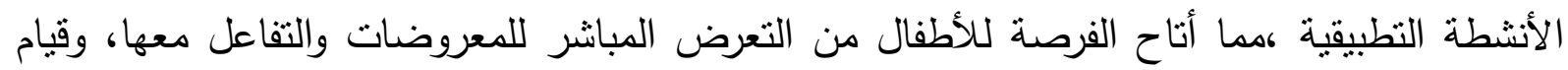

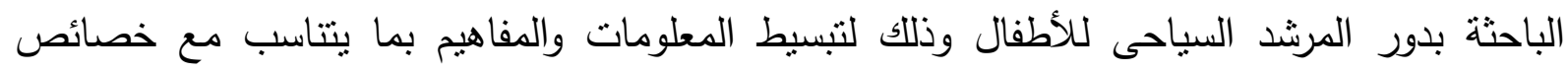

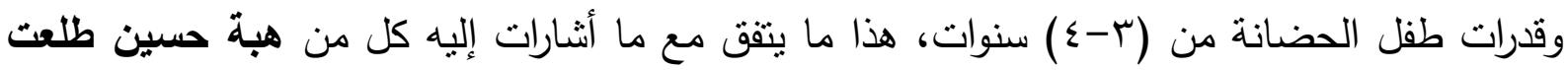

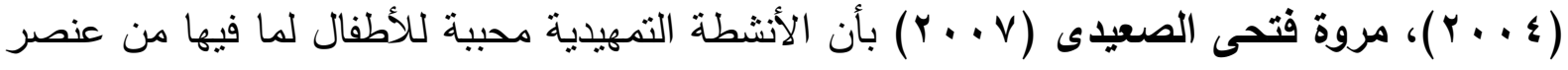

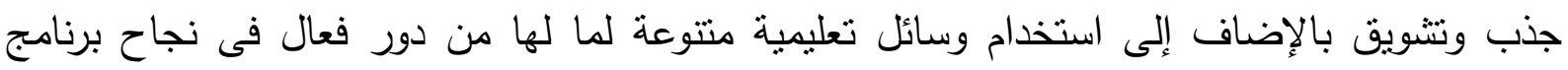

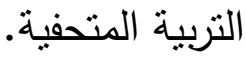

الفرض الرابع: نسبة التحسن لدى أطفال المجموعة التجريبية أعلى من أطفال المجموعة الضابطة على مقياس بعض المفاهيم الحضارية لمصر الفرعونية لطفل الحضانة من (ب-ـ) سنوات.

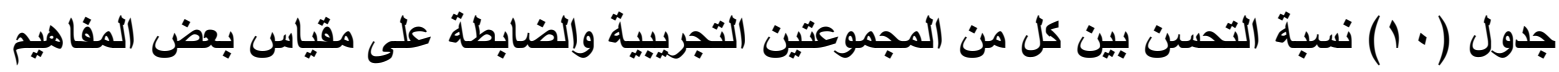
الحضارية لمصر الفرعونية

\begin{tabular}{|c|c|c|c|}
\hline نسبة التحسن & المجموعة الضابطة & التجريبة التجمة & الأبعاد \\
\hline$\% \circ r, \wedge$ & $1+, 0$ & $r \wedge, 0$ & الحقائق والمعارف \\
\hline$\% \leq 4, \leqslant$ & $\vee, \wedge$ & $I T, V$ & المهارات \\
\hline$\% r v, \wedge$ & $v, 1$ & $1 \leqslant, 9$ & قواعد السلوك \\
\hline$\% \leqslant \wedge, 7$ & $r r, 0$ & $9 ., 0$ & الارجة الكلية \\
\hline
\end{tabular}




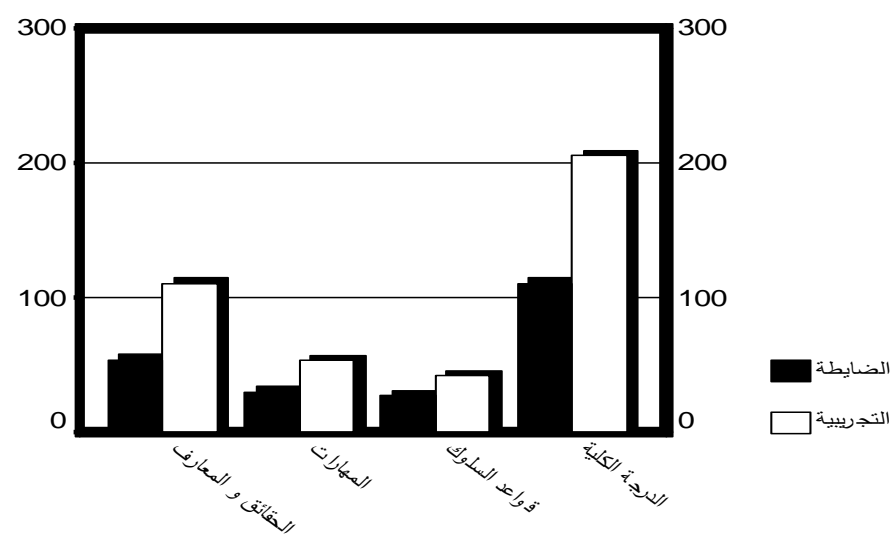

يوضح شكل (ب) نسبة التحسن بين أطفال المجموعتين التجربيية والضابطة على مقياس بعض المفاهيم الحضارية لمصر الفرعونية لطفل الحضانة من (r-ع) سنوات.

\section{تفسير نتيجة الفرض الرابع:}

يتضح من الفرق النسبى التحسن للمجموعة التجريبية أعلى من نسبة التحسن للمجموعة الضابطة، وهذا يدل على فاعلية برنامج التربية المتحفية، وترجع الباحثة ذلك إلى تتوع وتعدد أنتطة البرنامج فضلاً

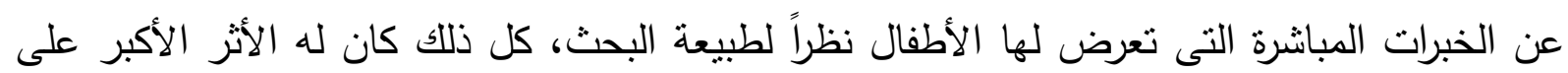
تتمية بعض المفاهيم الحضارية لمصر الفرعونية مما يحقق صحة هذا الفرض. الفرض الخامس لاتوجد فروق ذات دلالة إحصائية بين متوسطات درجات أطفال المجموعة التجربيية فى القياسين البعدى و التتبعى على مقياس بعض المفاهيم الحضارية لمصر الفرعونية لطفل الحضانة من (س-ع) سنوات. جدول ( 1 ) الفروق بين متوسطات درجات أطفال المجموعة التجريبية فى القياسين البعدى و

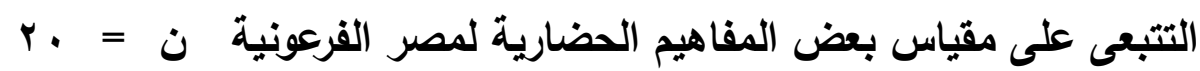

\begin{tabular}{|c|c|c|c|c|c|}
\hline \multirow[t]{2}{*}{ ا تجاه الدلالة } & \multirow[t]{2}{*}{ مستوى } & \multirow[t]{2}{*}{$ت$} & \multicolumn{2}{|c|}{ 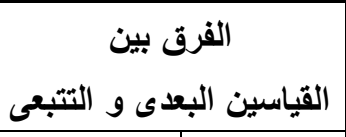 } & \multirow[t]{2}{*}{ المتغيرات } \\
\hline & & & مج ح ف & م ف & \\
\hline فى اتجاه القياس التتبعى & دالة عند مستوى 1 ., , & 19,7 & 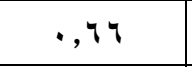 & $r, \cdot r$ & الحقائق والمعارف \\
\hline فى اتجاه القياس التتبعى & دالة عند مستوى ه ., . & $1, v_{0}$ & $\varepsilon, 07$ & $1, \leqslant 4$ & - - المهارات \\
\hline فى اتجاه القياس التتبعى & دالة عند مستوى 1 .,. & $\varepsilon, V$ & $1,1 \leq$ & 1 & - - قواعد السلوك \\
\hline فى اتجاه القياس التتبعى & دالة عند مستوى 1 ., . & $\varepsilon, \wedge 4$ & $0, .7$ & $\varepsilon, 0$ & الارجة الكلية \\
\hline
\end{tabular}


يتضح من جدول (1) (1) وجود فروق دالة إحصائياً عند مستوى (., •بين متوسطات درجات أطفال المجموعة التجريبية فى القياسين البعدى و التتبعى على مقياس بعض المفاهيم الحضارية لمصر الفرعونية لطفل الحضانة من (ץ-؟) سنوات فى اتجاه القياس التتبعى.

\section{تفسير نتيجة الفرض الخامس:}

تقاعل الأطفال مع البرنامج المتحفى وتتمية والوعى الحضارى لديهم ، حيث إن تاريخ وحضارة أى شعب دائمة الأستمرار والتطور لا تقف عند حد معين تنصير أولياء الأمور بضرورة تتمية المفاهيم الحضارية

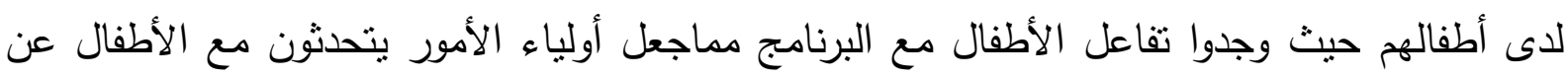

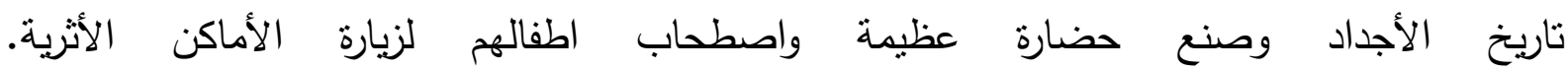

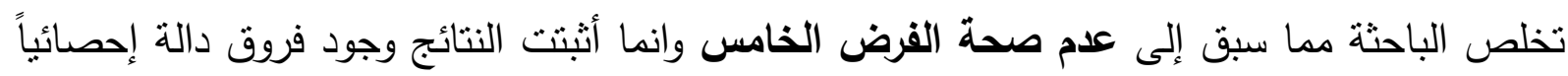

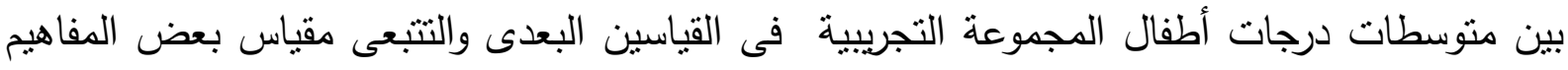
الحضارية لمصر الفرعونية لطفل الحضانة من (ب-؟) سنوات فى اتجاه القياس التنبعى.

$$
\text { نتائسج البحث: }
$$

() وجود فروق ذات دلالة إحصائية بين متوسطات درجات أطفال المجموعة التجريبية وأطفال

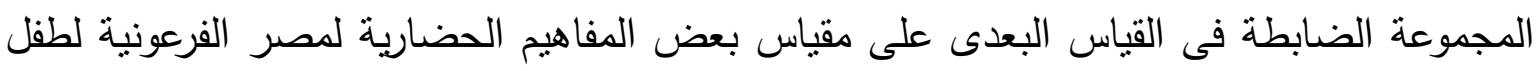
الحضانة من (r-乏) سنوات لصالح الهجموعة التجريبية. r عدم وجود فروق ذات دلالة إحصائية بين متوسطات درجات أطفال المجموعة الضابطة فى المئه القياسين القبلى والبعدى مقياس بعض المفاهيم الحضارية لمصر الفرعونية لطفل الحضانة . r) وجود فروق ذات دلالة إحصائية بين متوسطات درجات أطفال المجموعة التجريبية فى القياسين

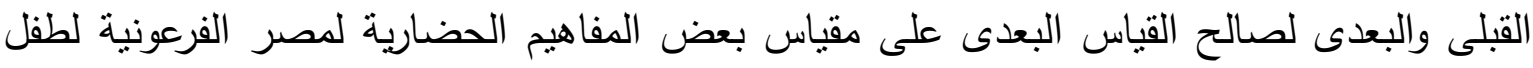

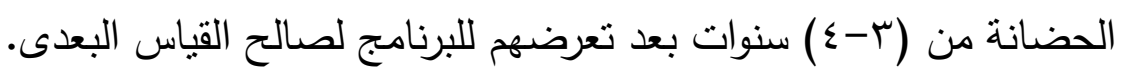

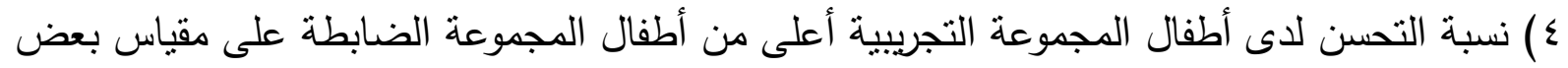

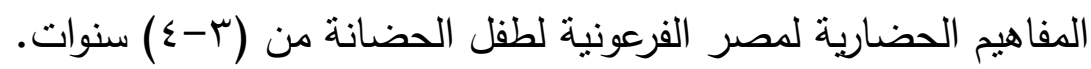
توصيات البحث:

( ) اهتمام القائمين والمهتمين بمرحلة دور الحضانة بالبرامج والأنشطة المتتوعة الخاصة بتتمية المفاهيم الحضارية للأطفال، وما يتعلق بها من حقائق ومعلومات ومهارات وسلوكيات.

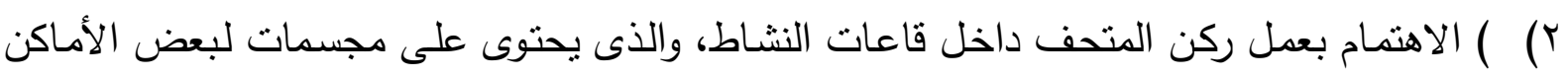

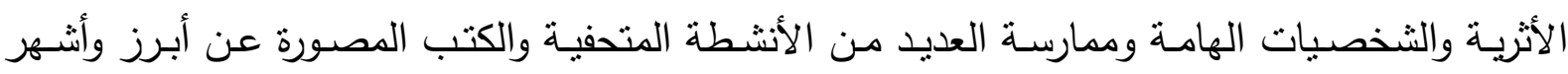
المبانى الأثرية والثخصيات الوطنية ... إلخ من ذللك. 
r) عقد دورات تدربيية لمعلمات ومشرفات دور الحضانة عن كيفية تتمية المفاهيم الحضارية لدى طفل

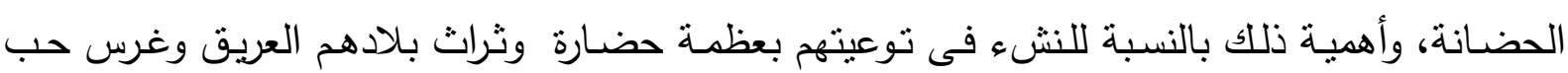
الوطن فى نفوسهم. ع) توعيـة أولياء الأمور بضـرورة الحديث مـع الأطفال عن حضـارة بلادهم واصطحاب الأطفال لزيارة الأماكن الأثرية لتتمية وغرس حب الوطن والانتماء فى نفوس الأطفال منذ الصغر . 0) اهتمـام دور الحضـانة بتتميـة حواس الطفل فهى مـدخل المعرفـة والتعلم والأكتشـاف مـع الاهتمـام بتوظيف اللعب والوسائل المختلفة بدور الحضانة لتتمة الوعى الأثرى والتارخى لديهم. مراجع البحث:

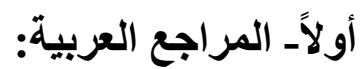
1 - أحمد حسن اللقانى، و آخرون (r 999 (). تدريس المو اد الإجتماعية. القاهرة: عالم الكتب.

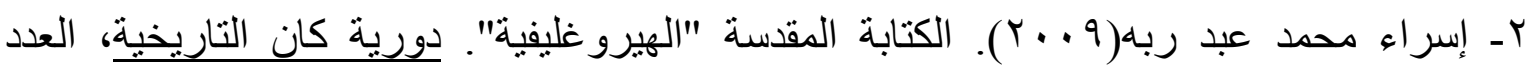
الثالث.

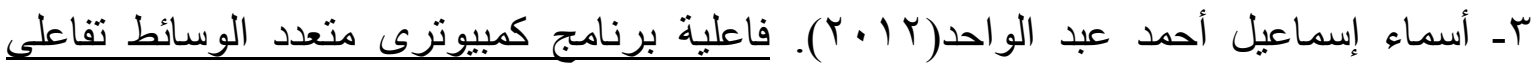
لإكساب بعض المفاهيم التاريخية لطفل الروضية. رسالة ماجستير غير منشورة، كلية رياض الأطفال، جامعة القاهرة. ع - أدولف إرمان( 999 (1) • ديانة مصر القديمة .(ترجمة : عبد المنعم أو بكر و محمد أنور شكرى) . القاهرة: الهيئة المصرية العامة للكتاب . هـ أمال أحمد محمد عامر(1) (1).أثز ممارسة التربية المتحفية على النمو المعرفي لطفل الروضة. رسالة ماجستير غير منشورة ، كلية رياض الأطفال ، جامعة الإسكندرية. 7- إميلى صادق ميجائيل(9 . . ب). فاعلية القصص التاريخية فى إكساب طفل الروضة المعرفة بالتاريخ. مجلة كلية التربية،جامعة طنطا، العدد( • ع). V- إيمان سعد السيد زناتى(Y I ( Y). فاعلية أدب الطفل فى تنمية الوعى بالتاريخ القومى لدى طفل الروضة فى ضوء المعايير القومية لرياض الأطفال. مجلة كلية رياض الأطفال، جامعة

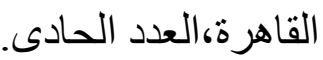
1ـ أيمن أبو الروس(Y . . r). كيف عاش قدماء المصريين لقطات من مصر الفرعونية .. أرض الحضارة ـ القاهرة: دار الطلائع للنشر و التوزيع و التصدير.

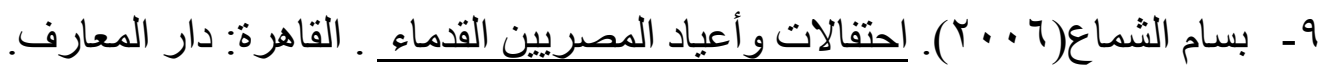




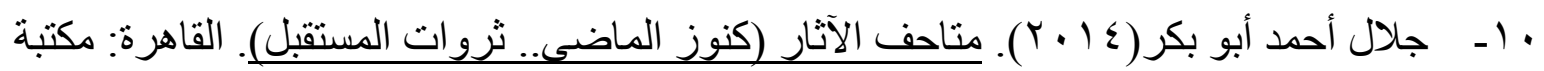

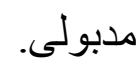

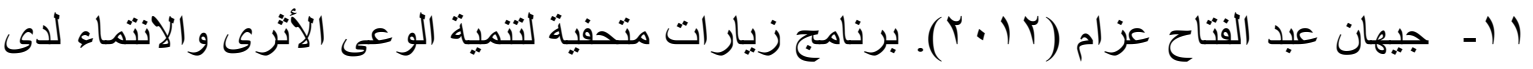

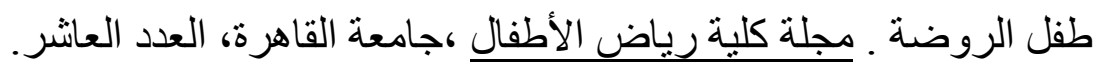

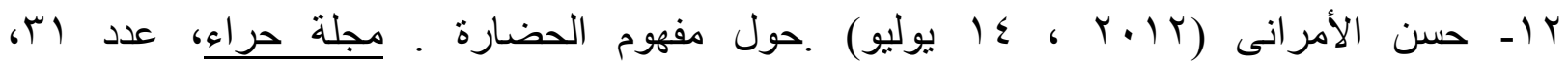
ص זr. (1)

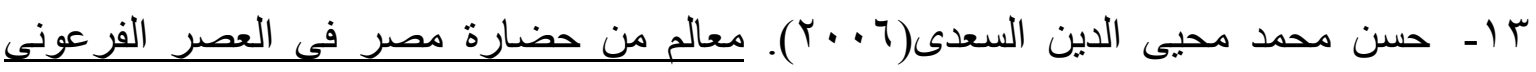
الإسكندرية: دار المعرفة الجامعية .

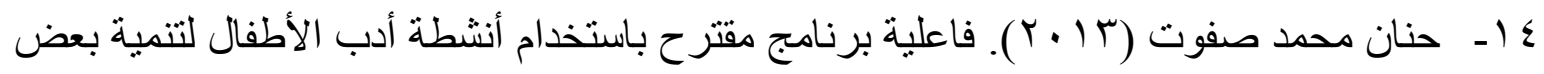

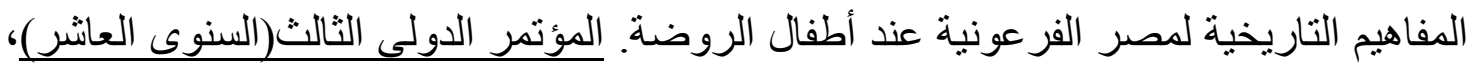

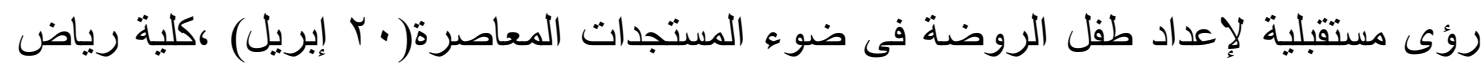

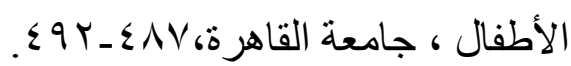

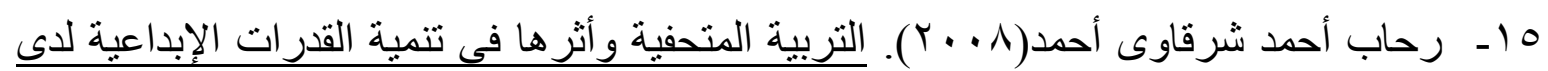
طفل الروضة. رسالة ماجستير غير منشورة ، كلية رياض الاطفال ، جامعة الإسكندرية.

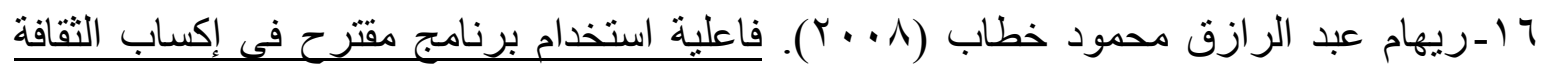
المتحفية لأطفال ما قبل المدرسة. رسالة ماجستير غير منشورة، معهد الدراسات العاليا للطفولة ، جامعة عين شمس.

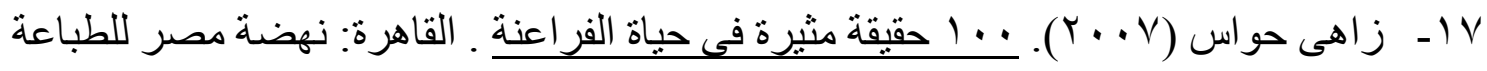
و النشر و التوزيع.

11 ا- زيدان نجيب حواثين و مفيد نجيب حواثين (1990). اتجاهات حديثة في تربية الطفل

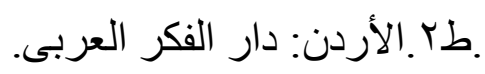

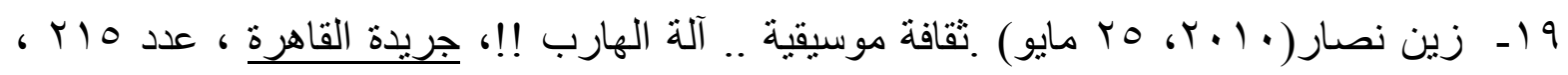
ص乏.

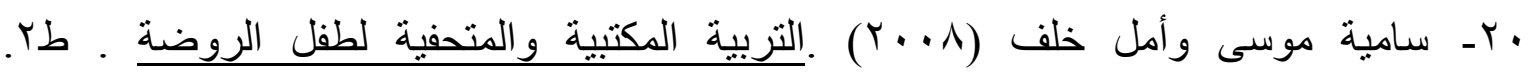

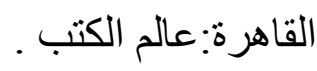

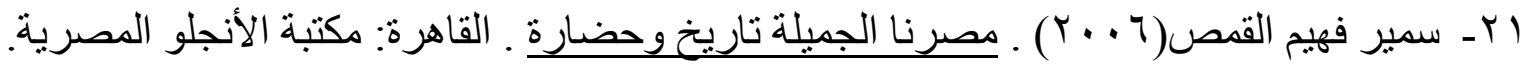

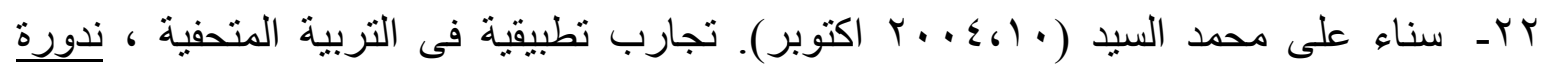

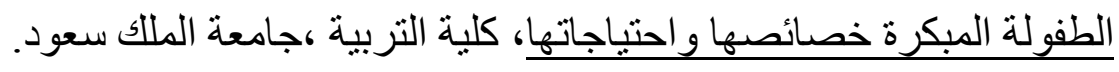




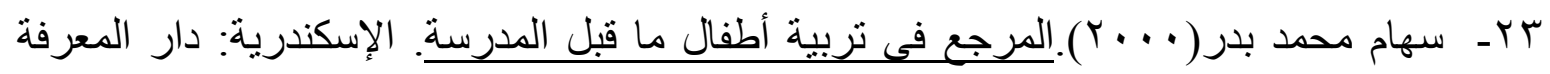
الجامعية.

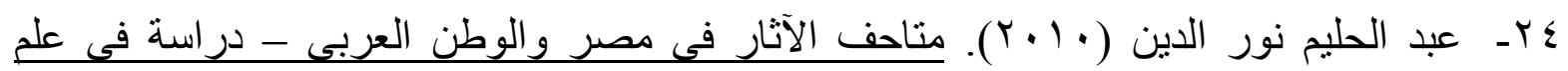
المتاحف . طץ. القاهرة: الأقصى للطباعة والتجارة و التوريدات.

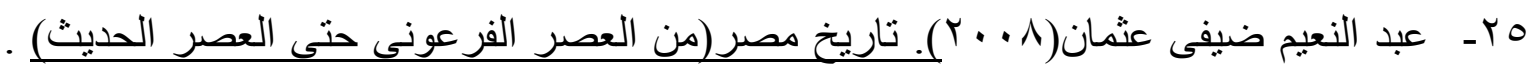
القاهرة: دار الرشاد.

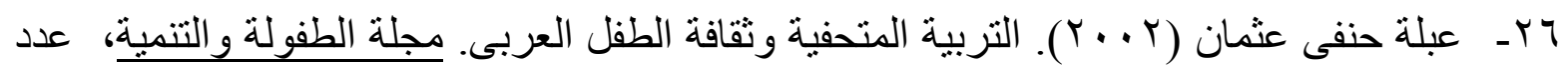
(7) المجلد الثانى ، المجلس العربى للطفولة والتنمية ، القاهرة.

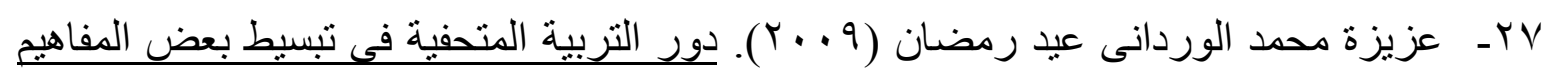
الجيولوجية لطفل الروضة. رسالة ماجستير غير منشورة ، كلية رياض الأطفال ، جامعة الإسكندرية.

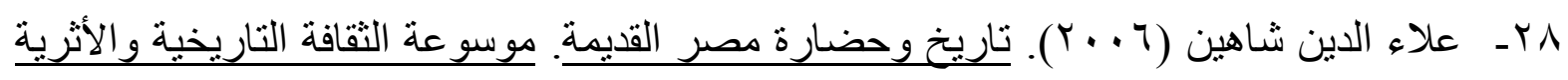
و والحضارية. القاهرة: دار الفكر العربى .

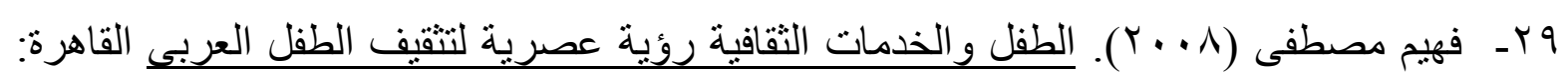
الدار العربية للكتاب. • ــ كارين بروكفليد (د.ت): الكتابة .(ترجمة : عمر فوزى حجاج) القاهرة: نهضة مصر للطباعة

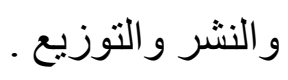

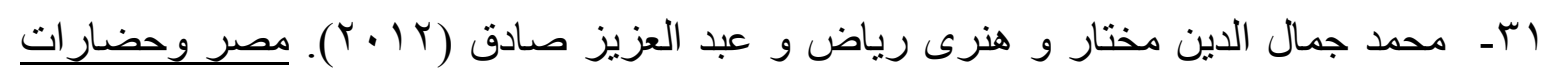
العالم القديم. وزارة التربية والتعليم. القاهرة: دار الكتب المصرية. Yr- محمد سيد حلاوة (11 (Y). أنشطة في مكتبات ومتاحف الأطفال . الإسكندرية: دار المعرفة الجامعية.

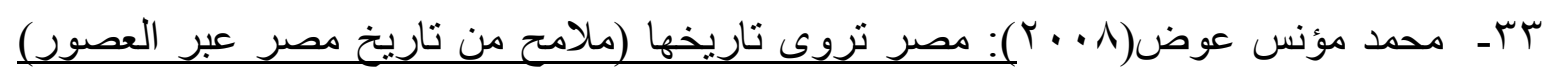

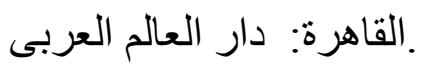

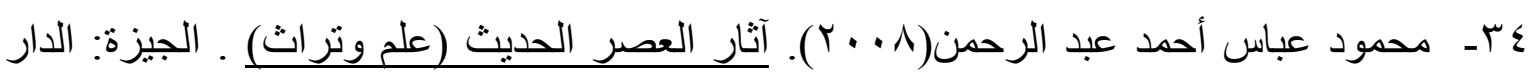
العالمية للنشر و التوزيع. هبـ ـ مروة محمد فتحى الصعيدى(V . . (Y).فعالية الأنشطة المتحفية فى الدراسات الاجتماعية لتنمية المفاهيم التاريخية و الوعى الأثرى لاى تلاميذ الصف الأول الإعدادى. رسالة ماجستير غير منشورة، جامعة حلوان. 


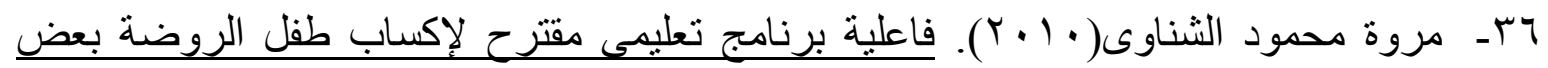

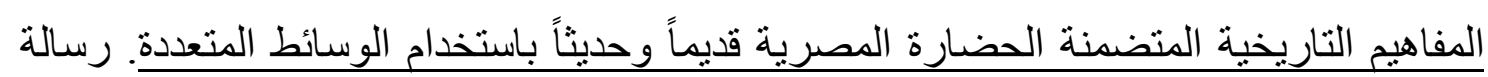

دكتور اه غير منشورة، كلية رياض الأطفال، جامعة الإسكندرية.

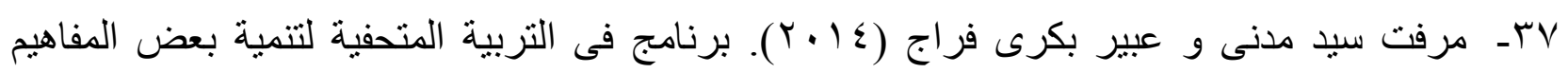

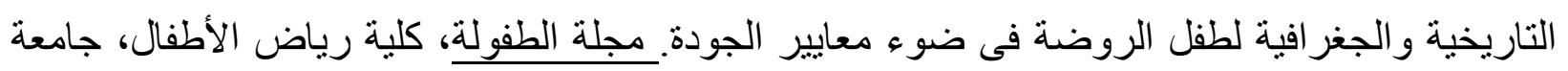

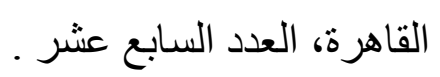

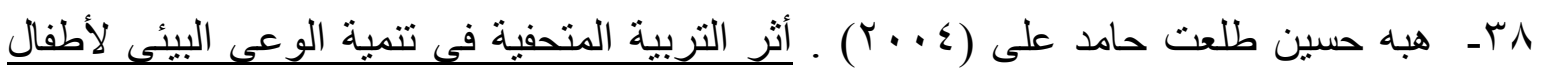
الروضة . رسالة دكتور اه غير منشورة ، كلية رياض الأطفال ، جامعة القاهرة ، القاهرة.

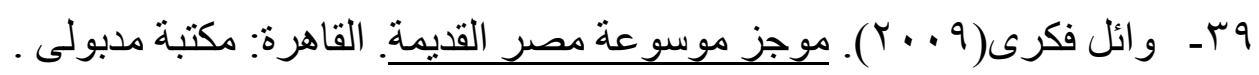

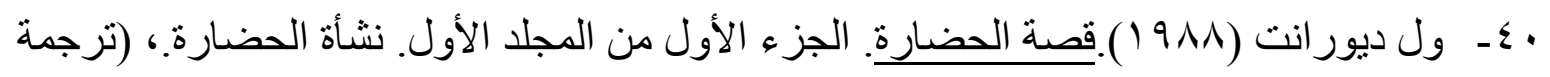
: زكى نجيب محمود ) الإدارة الثقافية فى جامعة الدول العربية.

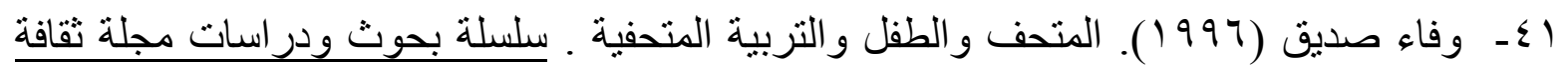

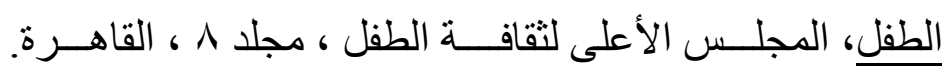

\section{ثانياً- المراجع الأجنبية:}

42- Amanda Miler(2004). Fall-Day In Kindergarten, Eric Clearing house elementary ,and Early Childhood Education.

43- Alston, Vermonja R.(2004). Race-crossings at the crossroads of African American travel in the Caribbean, Ph. D., The University of Arizona, 2004,[On- Line].

44- Barbara Wolf, Elizabeth Wood(2012). The Role of Museum Education intervention in developing some positive Behaviores among Preschool Children, Journal of Museum Education, Vol. (37), No.(1).

45- Doug,k(2009). Importance of starting the education of children in the initial stages of the educational history of the ancient world,v62,n3.

46- Carol Catron and Jan Allen (1998).Environment and Education the development of An out door experiential Learning Center for the Manitoba Museum, Eric-ED

47- Dennis Kamel (2005). Education Today The School in its Social Setting, Eric-ED 437908.

48- Golobeck, Susan L(2002). "Instructional models for early childhood education": ED468565.

http://www.ericfacilty.net/ericdiyests/ed468565.html2019/2011 
49- Greene, Wilma- prudhum (1998). Magarity, 1058iana, ed, in meseum and learning, aguide for family visits.

50- Hein, G.E.(1998). Learning in The Museum, U.S.A, Roultdega.

51- Jodidio,Ph.(2010).Architecture now!Museum, Taschen, Ital

52- Kinder, Anna M., Darras Bernara (2005). young child remand museum, the role of cultural context in early development Attitude Beliefs and behaviors.

53- Lee Ching, Fang (2002). The museum as an educational entity: The performative transformation of places into spaces, ProQuest Dissertations Publishing, 12-31

54- Meeks, D., Notion de(1988). "dieu et structure du pantheon dans

L'Egypte Anciennje” Revue de L'histoire des Religions 205/4.

55- Randy Bechtel, Robert Shumer (2006). Project Earth Science N.C Geological Survey.

56- Silverman, L.H \& O' Neil, M. (2004). Change and Complexity in The 21(st)-Century Museum : The Realrelics in Our Museums May Be The Ways We Think and work, Museum News, November - December.

57- Tortello , Rebecca Marie(2002). Children Get Your Culture: Jamaican Children and Their Museum Experiences. Informal Education and The Development of Individualism " Dissertation Abstracts (Volume: 63-04, 2002, Section: A,P.1299).

58- http://ar.wikipedia.org/wiki/ . 